\title{
Effects of interannual events (1997-2012) on the hydrography and phytoplankton biomass of Sebastián Vizcaíno Bay
}

\section{Efectos de eventos interanuales (1997-2012) sobre la variabilidad hidrográfica y biomasa del fitoplancton en bahía Sebastián Vizcaíno}

\author{
Luz María Martínez-Fuentes ${ }^{1}$, Gilberto Gaxiola-Castro ${ }^{1 \S *}$, Eliana Gómez-Ocampo ${ }^{1}$, Mati Kahru ${ }^{2}$ \\ ${ }^{1}$ Departamento de Oceanografía Biológica, Centro de Investigación Científica y de Educación Superior de \\ Ensenada, Carretera Ensenada-Tijuana No. 3918, Zona Playitas, Ensenada, Baja California, CP 22860, \\ México. \\ ${ }^{2}$ Scripps Institution of Oceanography, University of California, San Diego, La Jolla, California, USA. \\ $\S$ Monterey Bay Aquarium Research Institute, Moss Landing, California, USA (sabbatical). \\ * Corresponding author. E-mail: ggaxiola@cicese.mx
}

\begin{abstract}
Sebastián Vizcaíno Bay (Baja California Peninsula, Mexico) presents hydrographic conditions and phytoplankton biomass corresponding to a temperate/subtropical transition zone affected by large-scale tropical and subtropical events and those events originating in the subpolar Pacific region. Conditions in the first $50 \mathrm{~m}$ depth of the bay are mostly temperate (average temperature: $15.5^{\circ} \mathrm{C}$; average salinity: 33.6) and mesotrophic (phytoplankton biomass: $>1 \mathrm{mg} \mathrm{m}^{-3}$ ). During spring and summer the bay is heavily influenced by the water transported by the California Current and the coastal upwelling generated off Punta Canoas. During the rest of the year the hydrography and phytoplankton biomass are mostly associated with subtropical conditions. The ENSO events arising in the period 1997-2012 affected the bay's water column. The extreme 1997-1998 El Niño generated increases of $\sim 8^{\circ} \mathrm{C}$ in temperature and $\sim 0.8$ in salinity. Local dynamic processes decreased the effects of moderate and weak El Niño events on phytoplankton biomass, with possible changes in the plankton functional groups. Due to the mostly temperate environment of the bay, the moderate 1998-2000 and 2010-2011 La Niña events did not generate a substantial change in the hydrography and phytoplankton biomass. However, the abundant subarctic water inflow in the period 2002-2006 abruptly decreased salinity and led to increased stratification of the water column and a reduction in phytoplankton chlorophyll.
\end{abstract}

Key words: long-term variability, hydrography, chlorophyll, ENSO cycle, Sebastián Vizcaíno Bay.

RESUMEN. Bahía Sebastián Vizcaíno (península de Baja California, México) presenta condiciones hidrográficas y biomasa del fitoplancton correspondientes a una zona transicional subtropical-templada, afectada por eventos tropicales y subtropicales de gran extensión espacial y temporal, y por eventos originados en la región subpolar del Pacífico. En los primeros $50 \mathrm{~m}$ de profundidad de la bahía, el ambiente es mayormente templado (temperatura promedio: $15.5^{\circ} \mathrm{C}$; salinidad promedio: 33.6 ) y mesotrófico (biomasa del fitoplacton: $>1 \mathrm{mg} \mathrm{m}^{-3}$ ). Durante primavera y verano la bahía está fuertemente influenciada por el agua transportada por la corriente de California y por las surgencias costeras generadas frente a punta Canoas. Durante el resto del año la hidrografía y biomasa del fitoplancton corresponden mayormente a condiciones sobtropicales. Los eventos de ENSO en el periodo 1997-2012 impactaron la columna de agua de la bahía. El Niño 1997-1998, que fue el de mayor magnitud, generó incrementos de $\sim 8{ }^{\circ} \mathrm{C}$ en la temperatura y de $\sim 0.8$ en la salinidad de la columna de agua. Los procesos dinámicos locales disminuyeron los efectos de los eventos de El Niño moderados y débiles sobre la biomasa del fitoplancton, aunque posiblemente hubo efectos en los grupos funcionales del plancton. Debido al ambiente mayormente templado de la bahía, los eventos moderados de La Niña 1998-2000 y La Niña 2010-2011 no tuvieron un cambio sustancial en la hidrografía ni en la biomasa del fitoplancton. Sin embargo, el ingreso de agua subártica en el periodo 2002-2006 disminuyó abruptamente la salinidad, lo que resultó en mayor estratificación de la columna de agua y reducción de la clorofila del fitoplancton.

Palabras clave: variabilidad de largo plazo, hidrografía, clorofila, ciclo ENSO, bahía Sebastián Vizcaíno.

\section{INTRODUCTION}

Sebastián Vizcaíno Bay (SVB), the largest coastal water body in the northeastern region of the Pacific Ocean, is located on the west coast of the Baja California Peninsula (Mexico), in the southern region of the California Current System (CCS) (Fig. 1a). Situated in a transition zone between temperate and subtropical waters, its physical and biological

\section{INTRODUCCIÓN}

Bahía Sebastián Vizcaíno (BSV) es el cuerpo de agua costero más extenso de la región nororiental del océano Pacífico y está localizado en la costa occidental de la península de Baja California, en la sección sureña del Sistema de la Corriente de California (SCC) (Fig. 1a). Esta bahía presenta aguas de transición templadas y subtropicales 

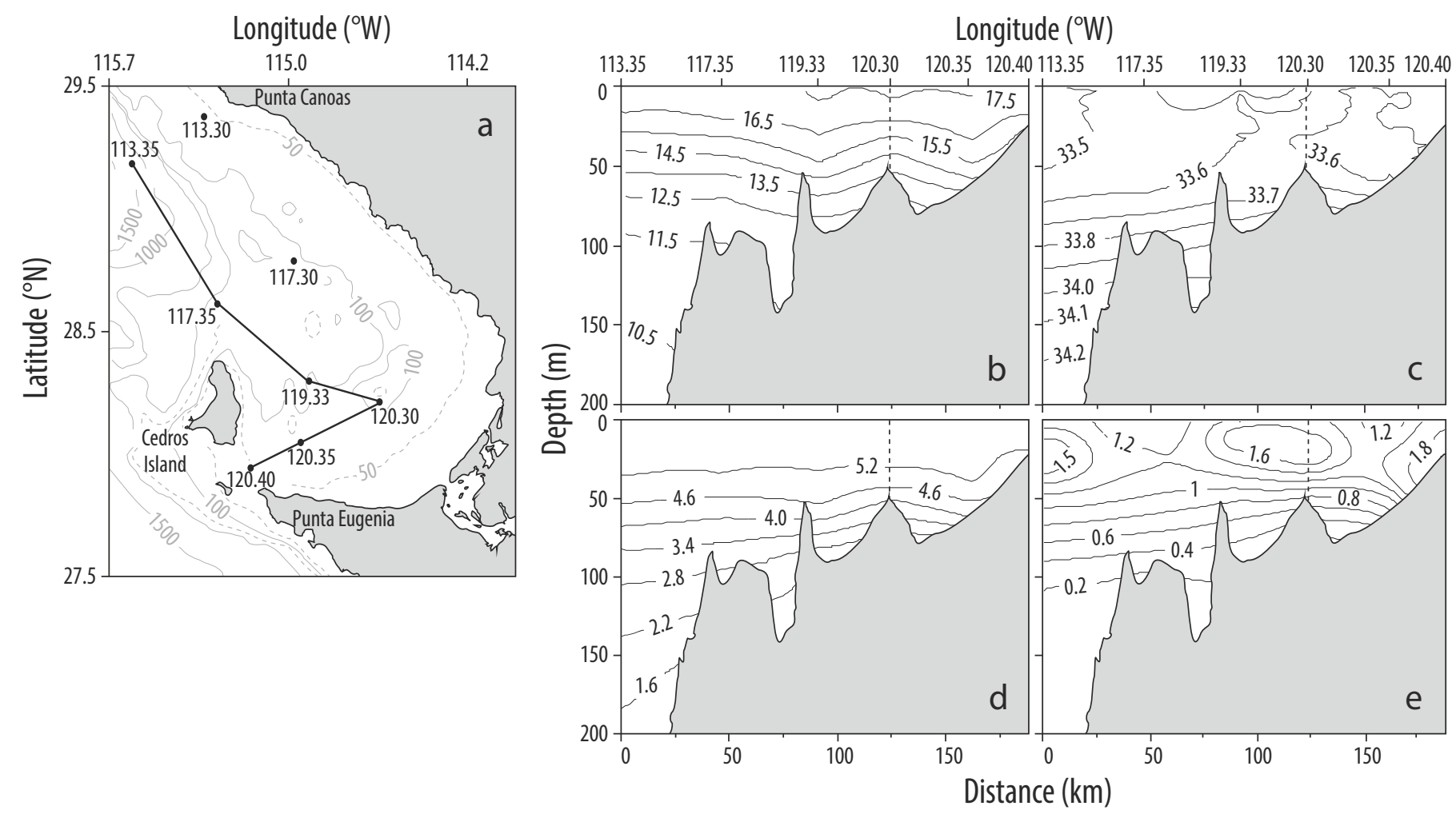

Figure 1. (a) Location of the hydrographic stations occupied during the IMECOCAL cruises (1998-2012) in Sebastián Vizcaíno Bay (Baja California Peninsula, Mexico). The bathymetry is given in meters (taken from NOAA: http://www.ngdc.noaa.gov/mgg/bathymetry/ relief.html). The transect used for the vertical sections of the variables measured during the cruises is indicated with a continuous black line. Vertical profiles for long-term average (b) temperature $\left({ }^{\circ} \mathrm{C}\right)$, (c) salinity, (d) dissolved oxygen $\left(\mathrm{mL} \mathrm{L}^{-1}\right)$, and $(\mathbf{e})$ chlorophyll $a\left(\mathrm{mg} \mathrm{m}{ }^{-3}\right)$; the dashed line indicates the change in transect direction at station 120.30 . The distance $(\mathrm{km})$ refers to the distance between stations 113.35 and 120.40 .

Figura 1. (a) Localización de las estaciones hidrográficas ocupadas durante los cruceros IMECOCAL (1998-2012) en bahía Sebastián Vizcaíno (península de Baja California, México). La batimetría está dada en metros (tomada de la NOAA: http://www.ngdc.noaa.gov/mgg/ bathymetry/relief.html). El transecto utilizado para las secciones verticales de las variables medidas durante los cruceros se representa con una línea negra continua. Perfiles verticales del promedio de largo plazo de (b) temperatura $\left({ }^{\circ} \mathrm{C}\right)$, (c) salinidad, (d) oxígeno disuelto (mL $\mathrm{L}^{-1}$ ) y (e) clorofila $a\left(\mathrm{mg} \mathrm{m}^{-3}\right)$; la línea punteada indica el cambio de dirección del transecto a partír de la estación 120.30. La distancia (km) se refiere a la separación entre las estaciones 113.35 y 120.40 .

characteristics make it an important habitat for phytoplankton and zooplankton, and several species of high commercial value are caught in its waters, including Pacific sardine, sole, lobster, shrimp, sharks, and rays. Given the importance of this area, a better understanding is needed of the temporal and spatial variability of the environmental conditions and phytoplankton biomass, which forms the basis of the epipelagic food chain.

According to long-term data available for the CCS, the region off the Baja California Peninsula has recently been affected by diverse climatic and oceanographic events, especially during the period from 1997 to 2012. The most notable events because of their magnitude and effects on the pelagic ecosystem have been the 1997-1998 El Niño and the 1998-1999 La Niña (Lynn et al. 1998; Hayward et al. 1999; Durazo and Baumgartner 2002; Lavaniegos et al. 2002, 2003). From 2002 to 2006, an anomalous intrusion of a large con características físico-biológicas que la hacen un hábitat muy importante para el fitoplancton y zooplancton, y para especies de alto valor comercial de la región, como la sardina del Pacífico, lenguado, langosta, camarón, tiburones y rayas. Debido a la importancia de esta área, se requiere contar con un mayor conocimiento de la variabilidad temporal y espacial de las condiciones ambientales y la biomasa del fitoplancton, la cual constituye la base de la trama trófica marina que se desarrolla en la zona epipelágica.

De acuerdo con la información de largo plazo para el SCC, la región frente a la península de Baja California ha sido impactada recientemente por diversos eventos climáticos y oceanográficos, principalmente durante el periodo 1997-2012. Los eventos más sobresalientes por su magnitud y efectos registrados en el ecosistema pelágico han sido El Niño 1997-1998 y La Niña 1998-1999 (Lynn et al. 1998; Hayward et al. 1999; Durazo y Baumgartner 2002; 
volume of subarctic water affected the epipelagic ecosystem of the CCS off the west coast of the peninsula (Venrick et al. 2003; Durazo et al. 2005; Gaxiola-Castro et al. 2008, 2010b), causing changes in phytoplankton biomass and production (Herrera-Cervantes et al. 2014, Espinosa-Carreón et al. 2015) and in zooplankton abundance (Lavaniegos 2014, Lavaniegos et al. 2015). Other interannual events that have had a more minor impact are the moderately strong El Niño events of 2002-2003 (Venrick et al. 2003) and 2009-2010 (Bjorkstedt et al. 2010), and less intense La Niña events mainly during 2007-2009 (McClatchie et al. 2009) and 2010-2011 (Bjorkstedt et al. 2011). While information exists on the effects of these large-scale events on the CCS, and especially the region off Baja California covered by the IMECOCAL (Spanish acronym for Mexican Research of the California Current) program, the spatial and temporal effects on the hydrography and phytoplankton biomass within SVB have not been specifically examined.

In this study we evaluate the effects of the interannual oceanographic variability observed in the southern region of the California Current (CC) during the period from 1997 to 2012 on some environmental variables and the phytoplankton biomass in SVB, in order to better understand the regional oceanography and assess the effects on phytoplankton production.

\section{MATERIALS AND METHODS}

\section{Study area}

The most notable characteristic of the circulation in SVB is the greater inflow of surface and subsurface water through the northern mouth of the bay due to the predominant north-south flow of the CC and because the southern mouth is very narrow and has a maximum sill depth of $\sim 50 \mathrm{~m}$ (Fig. 1a), restricting water exchange below this depth. Another difference with similar northwestern Pacific bays is the formation of an anticyclonic eddy in the central area (McEwen 1916, Dawson 1952), derived due to the southward advection, the Coriolis effect on the surface circulation, and the elongated shape of the bay. The anticyclonic eddy has a maximum depth of $60 \mathrm{~m}$ (Amador-Buenrostro et al. 1995) in an area that has a depth of about $150 \mathrm{~m}$ (Fig. 1a). Wyllie (1961) characterized the influence within the bay of CC water, subtropical water, and water derived from coastal upwelling, with surface temperature of 12 to $14^{\circ} \mathrm{C}$ and salinity of 33.60 to 33.65 . This author found that surface water temperature increases in the central bay $\left(19-21^{\circ} \mathrm{C}\right)$ in summer, and it decreases $\left(15-18^{\circ} \mathrm{C}\right)$ and salinity increases $(\sim 34)$ in winter.

The bay presents marked seasonal variability. In spring and summer, coastal upwelling and intrusions of subarctic and transformed equatorial waters occur off Punta Canoas (Mancilla-Peraza et al. 1993), one of the most productive
Lavaniegos et al. 2002, 2003). De 2002 a 2006, en la región frente a la costa occidental de la península de Baja California hubo un ingreso anómalo de un gran volumen de agua subártica que afectó el ecosistema epipelágico del SCC (Venrick et al. 2003; Durazo et al. 2005; Gaxiola-Castro et al. 2008, 2010b) y ocasionó cambios en la biomasa y producción del fitoplancton (Herrera-Cervantes et al. 2014, EspinosaCarreón et al. 2015) y en la abundancia del zooplancton (Lavaniegos 2014, Lavaniegos et al. 2015). Otros eventos interanuales que han tenido efectos menores en la región son los eventos de El Niño de intensidad moderada de 2002-2003 (Venrick et al. 2003) y 2009-2010 (Bjorkstedt et al. 2010) y La Niña de menor intensidad principalmente en los periodos 2007-2009 (McClatchie et al. 2009) y 2010-2011 (Bjorkstedt et al. 2011). Aunque existe información de los efectos de estos eventos de gran escala temporal para el SCC y particularmente la región frente a Baja California estudiada por el programa Investigaciones Mexicanas de la Corriente de California (IMECOCAL), las afectaciones espaciales y temporales sobre la hidrografía y la biomasa del fitoplancton dentro de BSV no han sido evaluadas en forma específica.

En este trabajo se analizan los efectos de la variabilidad oceanográfica interanual observada en la zona sur de la corriente de California (CC) durante el periodo de 1997 a 2012 sobre algunas variables ambientales y la biomasa del fitoplancton en BSV, con el propósito de avanzar en el conocimiento de la oceanografía regional y estimar los efectos en la producción del fitoplancton.

\section{MATERIALES Y MÉTODOS}

\section{Área de estudio}

La característica más sobresaliente de la circulación en BSV es el mayor ingreso de agua superficial y subsuperficial por la boca norte de la bahía, debido al transporte dominante norte-sur del flujo de la CC y a que la boca sur es muy angosta y tiene una profundidad máxima en el umbral de $\sim 50 \mathrm{~m}$ (Fig. 1a), lo que restringe el intercambio de agua por debajo de esa profundidad. Otra de las diferencias con bahías similares del Pacífico nororiental es la formación de un remolino anticiclónico hacia el área central (McEwen 1916, Dawson 1952), el cual se deriva de la advección hacia el sur, del efecto de Coriolis sobre la circulación superficial y de la forma alargada de la bahía. Se ha determinado que el remolino anticiclónico tiene una profundidad máxima de $60 \mathrm{~m}$ (Amador-Buenrostro et al. 1995) en una zona con cerca de $150 \mathrm{~m}$ de profundidad (Fig. 1a). Wyllie (1961) caracterizó la influencia dentro de la bahía de agua transportada por la CC, agua subtropical y agua derivada de surgencias costeras, y registró una temperatura superficial de $12 \mathrm{a} 14^{\circ} \mathrm{C}$ y salinidad de 33.60 a 33.65. Este autor observó que en verano la temperatura superficial del agua se incrementa $\left(19-21^{\circ} \mathrm{C}\right)$ hacia el centro de la bahía, y en invierno la temperatura disminuye $\left(15-18^{\circ} \mathrm{C}\right)$ y la salinidad aumenta $(\sim 34)$. 
and intense coastal upwelling zones of the CC (PalaciosHernández et al. 1996). Northwesterly winds predominate in this area throughout most of the year (Amador-Buenrostro et al. 1995), and cold, nutrient-rich upwelled water is advected towards the central part of the bay.

During the 1997-1998 El Niño event, the phytoplankton biomass in the water column of SVB was similar to the longterm average (Gaxiola-Castro et al. 2010b). At the end of the event it increased moderately and there was a decrease in zooplankton mainly due to a lower abundance of copepods and euphausiids (Lavaniegos et al. 2003). The latter authors reported high variability in the abundance of centric diatoms at the surface, decreasing during the winter of 1998. During the El Niño event, the bay showed high richness of other phytoplankton groups such as armored dinoflagellates, cryptomonads, and nanoflagellates (Lavaniegos et al. 2003). Lavaniegos (1995) observed that the anticyclonic eddy present in SVB after the period of intense coastal upwelling (September) served to retain euphausiids until their metamorphosis into adults, their growth rate increasing due to the high temperature of the water in the center of the eddy. Lavaniegos (1995) also concluded that for Nyctiphanes simplex (Crustacea: Euphausiacea), the bay provides suitable conditions for recruitment and reproduction in autumn and for feeding in winter.

\section{In situ data acquisition}

For this study we used hydrographic data collected from 1998 to 2012 in SVB by the IMECOCAL program (Fig. 1a), during 52 surveys conducted aboard CICESE's R/V Francisco de Ulloa in winter, spring, summer, and autumn (usually January, April, July, and October). Water column temperature and salinity were measured with a Sea-Bird Electronics 911plus CTD calibrated by the manufacturer. The samples for phytoplankton chlorophyll $a$ and dissolved oxygen analyses were taken at different depths $(0,10,20,50$, 100,150 , and $200 \mathrm{~m}$, or until the depth permitted) with 5-L Niskin bottles attached to a rosette (General Oceanics). For the analysis of chlorophyll $a$, 1-L water subsamples from the Niskin bottles were collected in dark plastic containers and passed through Whatman GF/F filters that were stored in liquid nitrogen until their analysis in the laboratory. The concentration of chlorophyll $a$ was determined using the fluorometric method described by Yentsch and Menzel (1963) and Holm-Hansen et al. (1965), with the modifications made by Venrick and Hayward (1984). Phytoplankton fluorescence was determined using Turner Designs 10-AU-05 and Trilogy 7200-000 fluorometers, both calibrated with pure chlorophyll $a$ from spinach. The final concentration of the photosynthetic pigment was expressed in milligrams of chlorophyll $a$ per cubic meter. The samples for dissolved oxygen analysis were collected in 125-mL glass bottles and analyzed on board by the micro-Winkler method (Helm et al. 2009).
La bahía presenta una marcada variabilidad estacional. Durante primavera y verano, se producen surgencias costeras en la zona frente a punta Canoas y hay intrusión de agua subártica y agua ecuatorial transformada (Mancilla-Peraza et al. 1993). Esta área se encuentra dentro de una de las zonas de surgencias costeras más intensas y productivas de la CC (Palacios-Hernández et al. 1996). Durante la mayor parte del año predominan vientos del noroeste (Amador-Buenrostro et al. 1995), y el agua superficial fría y rica en nutrientes, derivada de las surgencias, es advectada hacia el interior de la bahía.

Durante el evento de El Niño 1997-1998, la biomasa del fitoplancton en la columna de agua de BSV fue similar al promedio de largo plazo (Gaxiola-Castro et al. 2010b). De acuerdo con Lavaniegos et al. (2003), al finalizar este evento hubo un incremento moderado en la biomasa del fitoplancton y una disminución del zooplancton debida principalmente a la abundancia menor de copépodos y eufáusidos. Estos autores reportaron una variabilidad alta en las abundancias superficiales de diatomeas céntricas, que disminuyó durante el invierno de 1998. Durante El Niño, la bahía mostró una riqueza alta en otros grupos del fitoplancton, como dinoflagelados tecados, criptomonas y nanoflagelados (Lavaniegos et al. 2003). Lavaniegos (1995) describió al remolino anticiclónico presente en BSV después del periodo de surgencias costeras intensas (septiembre) como un mecanismo de retención de eufáusidos hasta su metamorfosis adulta, ya que la tasa de desarrollo de los eufáusidos incrementó debido a la alta temperatura del agua en el centro del remolino. Además, Lavaniegos (1995) concluyó que para Nyctiphanes simplex (Crustacea: Euphausiacea), las condiciones de la bahía son adecuadas para su reclutamiento y reproducción en otoño y para su alimentación en invierno.

\section{Adquisición de datos in situ}

Para este estudio, se utilizaron datos hidrográficos recolectados de 1998 a 2012 en BSV por el programa IMECOCAL (Fig. 1a), durante 52 campañas realizadas con el B/O Francisco de Ulloa del CICESE en invierno, primavera, verano y otoño (usualmente en enero, abril, julio y octubre). La temperatura y salinidad de la columna de agua fue medida con un CTD Sea-Bird Electronics 911plus calibrado por el fabricante. Las muestras de agua para los análisis de clorofila $a$ del fitoplancton y oxígeno disuelto fueron tomadas a diferentes profundidades $(0,10,20,50,100,150 \mathrm{y}$ $200 \mathrm{~m}$, o hasta donde lo permitía el fondo) con botellas Niskin de $5 \mathrm{~L}$ de capacidad acopladas a una roseta oceanográfica (General Oceanics). Para el análisis de la clorofila $a$, se recolectó una submuestra de $1 \mathrm{~L}$ de agua de las botellas Niskin en recipientes oscuros de plástico y se pasó por filtros Whatman GF/F que se resguardaron en nitrógeno líquido hasta su análisis en el laboratorio. Para cuantificar la concentración de clorofila $a$, se utilizó el método fluorimétrico descrito por Yentsch y Menzel (1963) y Holm-Hansen et al. 


\section{Remote sensing data}

Monthly composites of sea surface temperature (SST, ${ }^{\circ} \mathrm{C}$ ), with a spatial resolution of $1 \times 1 \mathrm{~km}$, were obtained from the database generated by the Advanced Very High Resolution Radiometer (AVHRR) and Aqua Moderate Resolution Imaging Spectroradiometer (MODIS-A) for the period from 1997 to 2012. For the same period, monthly composites, with a spatial resolution of $1 \times 1 \mathrm{~km}$, of satelliteestimated chlorophyll (CHL; $\mathrm{mg} \mathrm{m}^{-3}$ ) were generated from Sea-viewing Wide Field-of-view Sensor (SeaWiFS), MODIS-A, MEdium Resolution Imaging Spectrometer (MERIS), and Visible Infrared Imaging Radiometer Suite (VIIRS) data. Using the products distributed by Ssalto/Duacs (AVISO, http://www.aviso.altimetry.fr/en/data/products/seasurface-height-products/global/adt-h.html), we obtained the monthly mean absolute dynamic topography (ADT, $\mathrm{cm}$ ) for the bay, interpolated with a spatial resolution of $0.25^{\circ} \times 0.25^{\circ}$. The monthly SST, ADT, and CHL anomalies were calculated as the difference of each month relative to the average month constructed for the complete time series (1997 to 2012). The WIM/WAM and MATLAB programs were used to decompress and handle the satellite images.

To analyze the possible effects of the El Niño/Southern Oscillation (ENSO) cycle on SVB, based on the Multivariate ENSO Index (MEI), the El Niño event of January 1998 and the La Niña event of January 1999 (http:// www.ggweather.com/enso/oni.htm) were selected as the most characteristic.

\section{RESULTS}

Based on a north-south transect of hydrographic stations of the IMECOCAL grid in the central part of SVB (Fig. 1a), vertical sections were elaborated with the time-series average of the variables measured in the period 1998-2012. Temperature showed a steep vertical gradient (thermocline) between 20 and $50 \mathrm{~m}$ depth (Fig. 1b). Surface temperature values were highest $\left(17.5^{\circ} \mathrm{C}\right)$ towards the central-southern part of the bay as a result of the water residence time associated with the predominantly southward circulation. Salinity values were homogeneous in the upper $100 \mathrm{~m}$ of the water column ( 33.5), increasing below this depth to 34.2 at $200 \mathrm{~m}$ (Fig. 1c). On average, there was a difference of approximately $70 \mathrm{~m}$ between the position of the thermocline (shallowest) and the halocline (deepest). Water from SVB showed similar characteristicas to water transported by the CC, with more changes in temperature than in salinity. Dissolved oxygen values were high (>5.0 mL L $\left.{ }^{-1}\right)$ in the upper $50 \mathrm{~m}$ (Fig. 1d) and phytoplankton biomass was $>1.0 \mathrm{mg} \mathrm{m}^{-3}$ (Fig. 1e).

Particularly conspicuous in the time series (1997-2012) of the mean values of the variables measured at $10 \mathrm{~m}$ depth at the IMECOCAL stations are the high temperature $\left(\sim 25^{\circ} \mathrm{C}\right)$ and salinity ( 34.4) values in October 1997 and January 1998 (Fig. 2a, b), during the intense 1997-1998 El Niño event
(1965), con las modificaciones de Venrick y Hayward (1984). La fluorescencia del fitoplancton se determinó con los fluorímetros Turner Designs 10-AU-05 y Trilogy 7200-000, ambos calibrados con clorofila a pura de espinaca. La concentración final del pigmento fotosintético se expresó en miligramos de clorofila $a$ por metro cúbico. Las muestras para el análisis de oxígeno disuelto se recolectaron en botellas de vidrio de $125 \mathrm{~mL}$ y se analizaron en el laboratorio del barco por el método micro-Winkler (Helm et al. 2009).

\section{Datos de sensores remotos}

En el periodo de 1997 a 2012 se obtuvieron compuestos mensuales de la temperatura superficial del mar (TSM, ${ }^{\circ} \mathrm{C}$ ), con resolución espacial de $1 \times 1 \mathrm{~km}$, de la base de datos generada por los sensores Advanced Very High Resolution Radiometer (AVHRR) y Moderate Resolution Imaging Spectroradiometer-Aqua (MODIS-A). Para el mismo periodo, se generaron compuestos mensuales de la clorofila estimada por satélite (CHL; $\mathrm{mg} \mathrm{m}^{-3}$ ), con una resolución espacial de $1 \times 1 \mathrm{~km}$, a partir de la base de datos de los sensores remotos del color del océano Sea-viewing Wide Field-ofview Sensor (SeaWiFS), MODIS-A, MEdium Resolution Imaging Spectrometer (MERIS) y Visible Infrared Imaging Radiometer Suite (VIIRS). A partir de los productos distribuidos por Ssalto/Duacs (AVISO, http://www.aviso.altimetry.fr/en/data/products/sea-surface-height-products/global/ adt-h.html), se obtuvieron los promedios mensuales de la topografía dinámica absoluta (TDA, cm) de la bahía, interpolados con una resolución espacial de $0.25^{\circ} \times 0.25^{\circ}$. Las anomalías mensuales de TSM, TDA y CHL se calcularon como la diferencia de cada mes con respecto al mes promedio construido de la serie de tiempo completa de 1997 a 2012. Se utilizaron los programas WIM/WAM y MATLAB para la descompresión y manejo de las imágenes de satélite.

Para mostrar los posibles efectos del ciclo de eventos de El Niño/Oscilación del sur (ENSO) dentro de la bahía, con base en el Índice Mutivariado del ENSO (MEI), se seleccionaron los eventos de El Niño de enero de 1998 y La Niña de enero de 1999 (http://www.ggweather.com/enso/oni.htm) como los más característicos.

\section{RESUlTADOS}

A partir de un transecto norte-sur de estaciones hidrográficas del programa IMECOCAL realizadas sobre la zona central de la bahía (Fig. 1a), se elaboraron secciones verticales con los promedios de largo plazo de las variables medidas en el periodo 1998-2012. La temperatura mostró un gradiente vertical pronunciado (termoclina) entre 20 y 50 m de profundidad (Fig. 1b). Los valores de temperatura superficial más altos se ubicaron en la parte centro-sur de la bahía $\left(17.5^{\circ} \mathrm{C}\right)$ como resultado de la residencia del agua generada por la circulación promedio dominante hacia el sur. Los valores de 
(http://www.ggweather.com/enso/oni.htm). Subsequently, the moderate 1998-2000 La Niña event caused temperature to decrease abruptly by $10^{\circ} \mathrm{C}$ and salinity by 0.8 (http:// www.ggweather.com/enso/oni.htm). The phytoplankton chlorophyll $a$ values were close to the average $\left(1.2 \mathrm{mg} \mathrm{m}^{-3}\right)$ during El Niño but increased to $3.5 \mathrm{mg} \mathrm{m}^{-3}$ during La Niña (Fig. 2c). Both physical variables decreased over the 14-year period, temperature by $4{ }^{\circ} \mathrm{C}$ and salinity by 0.4 , whereas chlorophyll did not show the same trend (Fig. 2c). From the beginning of 2003 to the end of 2006, average salinity decreased ( $\sim .5)$ but temperature was apparently not affected (Fig. 2a, b). This decrease in salinity coincided with the lowest chlorophyll concentration of all the time series (Fig. 2c), which continued until August 2007. The highest mean temperature and salinity values were recorded at the end of 1997 and beginning of 1998, and the low salinity and chlorophyll values showed a 4-year sequence (2003-2006).

The satellite-derived SST climatology for 1997-2012 showed a marked seasonal sequence, with lower values from December to May/June (Fig. 3). SST was generally $<16{ }^{\circ} \mathrm{C}$ from February to May due to the influence of cold water derived from coastal upwelling in spring and summer and still evident in June and July in the central bay (Fig. 3f, g). On average, SST was $>20^{\circ} \mathrm{C}$ in August, September, and October (Fig. $3 \mathrm{~h}-\mathrm{j}$ ). From May to November, the north-south spatial gradient intensified, warmer water occurring in the southern part of the bay. The climatology showed a moderate signal of warm surface water that entered by the southern mouth between July and November, which was not very extensive.

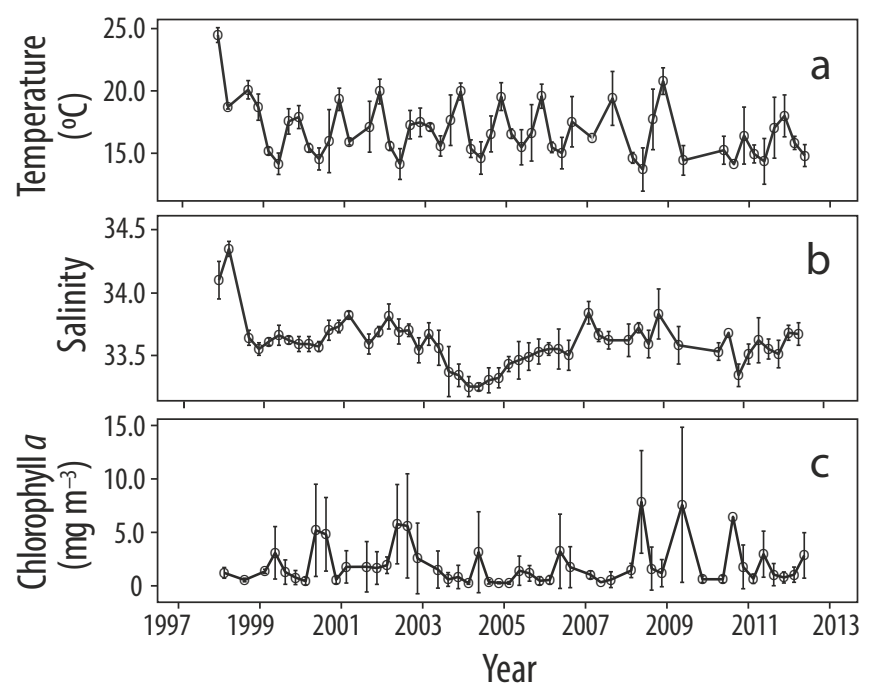

Figure 2. Time series of mean temperature (a), salinity (b), and chlorophyll $a$ (c) values at 10 m depth for Sebastián Vizcaíno Bay derived from IMECOCAL data. The bars represent the standard deviation of the mean.

Figura 2. Series de tiempo de valores promedio de temperatura (a), salinidad (b) y clorofila $a$ (c) a $10 \mathrm{~m}$ de profundidad para la bahía Sebastián Vizcaíno derivados de datos del programa IMECOCAL. Las barras representan la desviación estándar de la media. salinidad fueron homogéneos ( 33.5) en los primeros $100 \mathrm{~m}$ de la columna de agua e incrementaron por debajo de esta profundidad, hasta 34.2 a 200 m (Fig. 1c). En el promedio del periodo, hubo una diferencia de aproximadamente $70 \mathrm{~m}$ entre la posición vertical de la termoclina (más somera) y la haloclina (más profunda). El agua de BSV mantuvo condiciones similares al agua transportada por el flujo de la CC, con una mayor modificación en la temperatura que en la salinidad. Los valores de oxígeno disuelto fueron altos $\left(>5.0 \mathrm{~mL} \mathrm{~L}^{-1}\right)$ en los primeros $50 \mathrm{~m}$ de profundidad (Fig. 1d) y la biomasa del fitoplancton fue mayor que $1.0 \mathrm{mg} \mathrm{m}^{-3}$ (Fig. 1e).

En las series de tiempo de largo plazo (1997-2012) del promedio de las variables medidas a $10 \mathrm{~m}$ de profundidad en las estaciones IMECOCAL, sobresalieron los valores altos de temperatura $\left(\sim 25^{\circ} \mathrm{C}\right)$ y salinidad ( 34.4) en octubre de 1997 y enero de 1998 (Fig. 2a, b), durante un evento de El Niño 1997-1998 muy fuerte (http://www.ggweather.com/ enso/oni.htm). Posteriormente, se presentó un decremento abrupto de $10{ }^{\circ} \mathrm{C}$ en temperatura y 0.8 en salinidad, derivado de un evento moderado de La Niña 1998-2000 (http:// www.ggweather.com/enso/oni.htm). Los valores de la clorofila $a$ del fitoplancton fueron cercanos al promedio $\left(1.2 \mathrm{mg} \mathrm{m}^{-3}\right)$ durante El Niño e incrementaron a $3.5 \mathrm{mg} \mathrm{m}^{-3}$ durante La Niña (Fig. 2c). Como tendencia general, parece haber una disminución de largo plazo (14 años) en ambas variables físicas, de hasta $4{ }^{\circ} \mathrm{C}$ en temperatura y de 0.4 en salinidad, pero no se observó una tendencia similar en la clorofila (Fig. 2c). Desde inicios de 2003 y hasta finales de 2006 hubo una disminución ( 0.5) en el promedio de salinidad, pero no se observó un efecto evidente en la temperatura (Fig. 2a, b). Esta disminución en la salinidad se asoció con la concentración más baja de clorofila de toda la serie de tiempo (Fig. 2c), la cual permaneció hasta agosto de 2007. Como tendencia general, los valores más altos de temperatura y salinidad promedio en la bahía se presentaron al final de 1997 y principio de 1998, y se observó una secuencia de 4 años (2003-2006) de valores bajos para la salinidad y clorofila.

La climatología de la TSM derivada de imágenes de satélite para el periodo 1997-2012 mostró una secuencia estacional muy marcada, y los valores bajos se presentaron de diciembre a mayo/junio (Fig. 3). La temperatura $<16{ }^{\circ} \mathrm{C}$ fue más característica de febrero a mayo, cuando hubo influencia de agua fría originada por las surgencias costeras de primavera y verano y todavía evidente en junio y julio hacia el centro de la bahía (Fig. 3f, g). El promedio de largo plazo de la TSM fue $>20^{\circ} \mathrm{C}$ en agosto, septiembre y octubre (Fig. 3h-j). De mayo a noviembre, el gradiente espacial norte-sur se intensificó y el agua más cálida se ubicó hacia la zona sur de la bahía. En esta climatología se observó una señal moderada del agua cálida superficial que ingresó por la boca sur entre julio y noviembre, pero no se observó una amplia extensión espacial.

La clorofila derivada de datos de satélite mostró, más claramente que la TSM, la influencia del agua de surgencias 


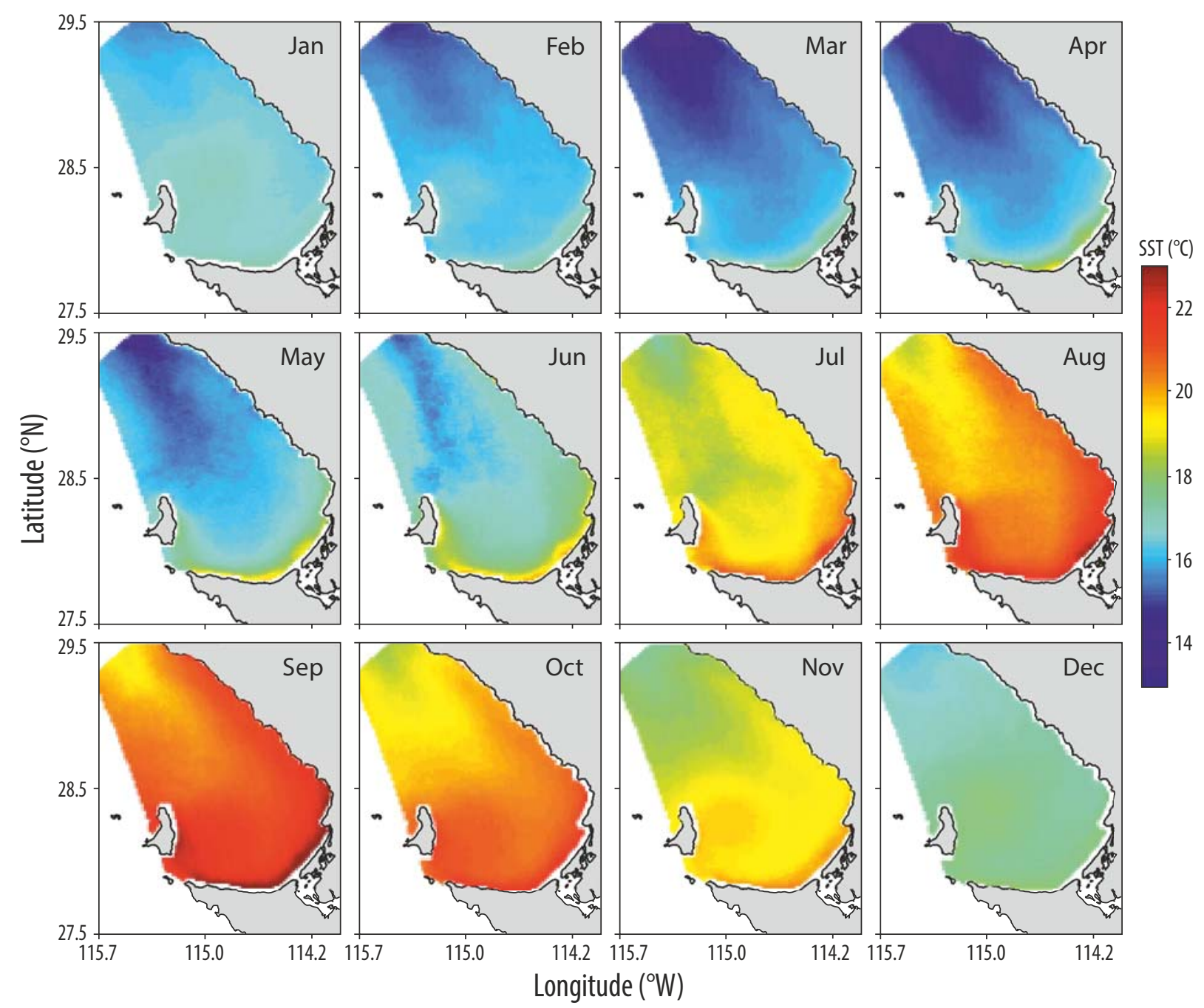

Figure 3. Sea surface temperature (SST, ${ }^{\circ} \mathrm{C}$ ) climatology (1997-2012) constructed from remote sensing data.

Figura 3. Climatología (1997-2012) de la temperatura superficial del mar (SST, ${ }^{\circ} \mathrm{C}$ ) derivada de datos obtenidos por sensores remotos.

The satellite-derived chlorophyll climatology showed, more clearly than SST, the influence of upwelled water in the bay, with higher values from March to June $\left(>5 \mathrm{mg} \mathrm{m}^{-3}\right)$ along the northeastern coast (Fig. 4c-f). From August to January the chlorophyll values were very low $\left(\sim 0.3 \mathrm{mg} \mathrm{m}^{-3}\right)$, and this period could be characterized as oligotrophic. Unlike SST, the NE-SW gradient was not evident for chlorophyll, since the influence of upwelled water advected southwards along the coast is more apparent. Chlorophyll concentrations are highest in the bay in spring and summer, associated with the intensification of the equatorward flow of the CC and with the coastal upwelling that typically occurs during this period off the west coast of the northern and central regions of the Baja California Peninsula.

Based on MEI, at least 4 El Niño events occurred in the Pacific Ocean during the period from 1997 to 2012, but the most dominant in terms of duration and magnitude was the 1997-1998 event (Fig. 5a). With regard to La Niña, the costeras en la bahía, con los valores más altos de marzo a junio ( $>5 \mathrm{mg} \mathrm{m}^{-3}$ ) extendidos a lo largo de la costa noreste (Fig. 4c-f). A partir de agosto y hasta enero, los valores de clorofila fueron muy bajos $\left(\sim 0.3 \mathrm{mg} \mathrm{m}^{-3}\right)$, lo que podría caracterizar a este periodo como de condiciones oligotróficas. A diferencia de la TSM, el gradiente NE-SW no fue evidente en la clorofila, ya que fue más notoria la influencia del agua derivada de las surgencias costeras advectada hacia el sur a lo largo de la costa. La mayor concentración de clorofila en la bahía ocurrió en primavera y verano, y está asociada a la intensificación del flujo de la CC hacia el ecuador y a los eventos de surgencias costeras característicos de esta época en las regiones norte y central de la costa occidental de la península de Baja California.

Con base en el MEI, en el océano Pacífico se presentaron al menos 4 eventos de El Niño entre 1997 y 2012, y el evento de 1997-1998 fue el más dominante en duración y magnitud (Fig. 5a). Con respecto a La Niña en la región del Pacífico 


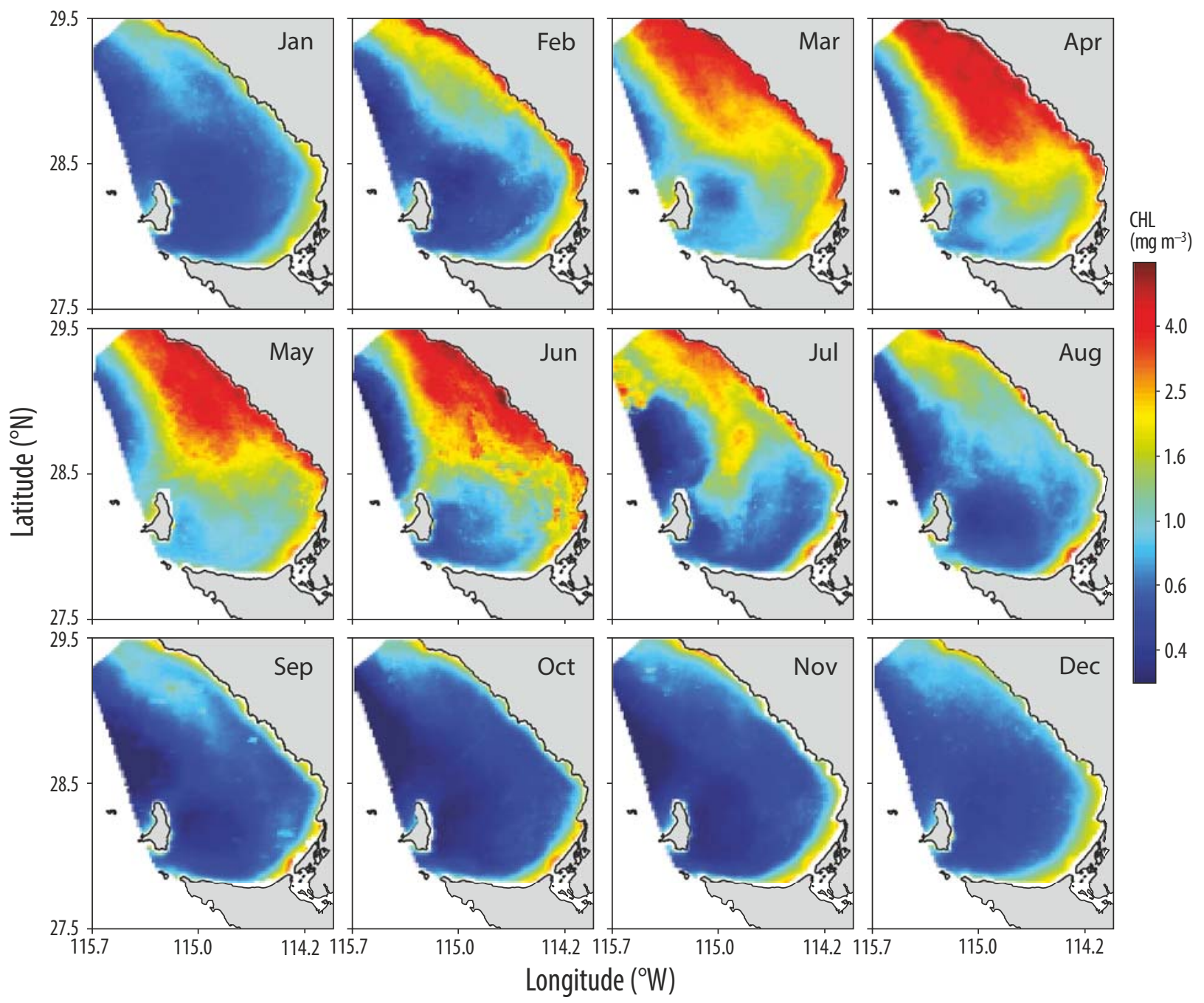

Figure 4. Chlorophyll (CHL, $\mathrm{mg} \mathrm{m}^{-3}$ ) climatology (1997-2012) constructed from remote sensing data.

Figura 4. Climatología (1997-2012) de la clorofila (CHL, $\mathrm{mg} \mathrm{m}^{-3}$ ) derivada de datos obtenidos por sensores remotos.

1998-2000 event and the moderate 2007-2008 and 2010-2011 events were identified in the subtropical Pacific region (Fig. 5a) (http://www.ggweather.com/enso/oni.htm). The 1997-2012 time series of monthly mean SST anomalies showed positive values greater than $0.5^{\circ} \mathrm{C}$ in several years, the most prominent being the values of $\sim 3.7^{\circ} \mathrm{C}$ in 1997-1998 (Fig. 5b); the 1997-1998 El Niño event has been identified as one of the strongest, similar to that of 1982-1983. The ADT anomalies showed a similar temporal trend to that of SST, the highest positive value $(\sim 20 \mathrm{~cm})$ occurring at the end of 1997 and beginning of 1998 (Fig. 5c). The effects derived from the weak and moderate El Niño events of 2006-2007 and 2010 were lower (Fig. 5c), but with positive values $(\sim 5 \mathrm{~cm})$. Except for some negative chlorophyll anomalies mainly during 1998, 2006-2007, and 2009-2010 (Fig. 5d), the weak and moderate El Niño events did not greatly affect the phytoplankton biomass near the surface. The satellite-derived chlorophyll time series subtropical, se identificaron principalmente el evento de 1998-2000 y los eventos moderados de 2007-2008 y 2010-2011 (Fig. 5a) (http://www.ggweather.com/enso/oni. htm). La serie de tiempo 1997-2012 de las anomalías de la TSM mensual promedio de BSV mostró valores positivos mayores que $0.5^{\circ} \mathrm{C}$ en varias etapas, pero los más sobresalientes fueron de $\sim 3.7^{\circ} \mathrm{C}$ y ocurrieron en el evento de 1997-1998 (Fig. 5b), identificado como un El Niño muy fuerte semejante al de 1982-1983. Las anomalías de la TDA mostraron una tendencia temporal muy similar a las de la TSM. El valor positivo más alto $(\sim 20 \mathrm{~cm})$ de la TDA se observó a finales de 1997 e inicios de 1998 (Fig. 5c). Los efectos derivados de los eventos de El Niño débiles y moderados de 2006-2007 y 2010 fueron menores (Fig. 5c), pero con valores positivos ( $\sim 5 \mathrm{~cm}$ ). Excepto algunos valores negativos en las anomalías de clorofila principalmente durante 1998, 2006-2007 y 2009-2010 (Fig. 5d), los eventos de El Niño débiles y moderados no afectaron de manera importante 

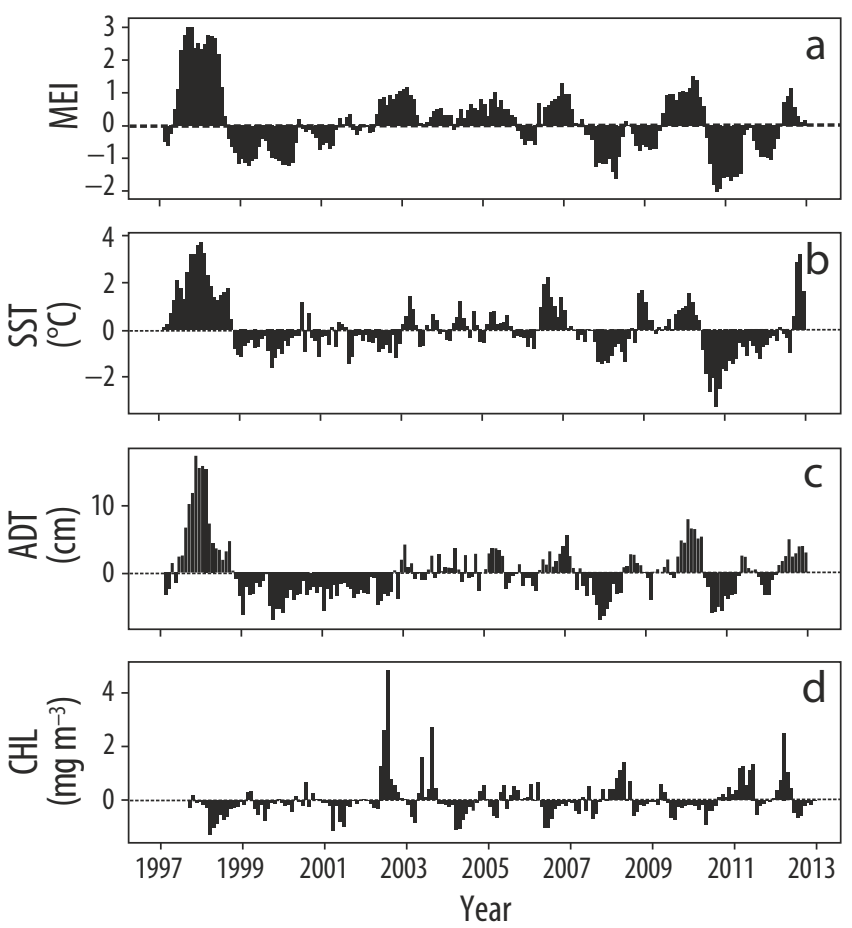

Figure 5. Time series of the Multivariate ENSO Index (MEI) (a) and of the monthly sea surface temperature (SST) (b), absolute dynamic topography (ADT) (c), and chlorophyll (CHL) (d) anomalies derived from remote sensing data. Positive anomalies = El Niño; negative anomalies = La Niña.

Figura 5. Series de tiempo del Índice Multivariado ENSO (MEI) (a) y de las anomalías mensuales de la temperatura superficial del mar (SST) (b), topografía dinámica absoluta (ADT) (c) y clorofila (CHL) (d) derivadas de sensores remotos. Anomalías positivas = El Niño; anomalías negativas = La Niña.

revealed high positive anomalies in 2002 and 2003, and to a lesser extent in 2011 and 2012 (Fig. 5d), without any direct relation to the ENSO cycle. The SST and ADT series revealed that 2 events clearly impacted SBV: the 1997-1998 El Niño (high positive anomalies) and the 2010-2012 La Niña (negative anomalies).

During the 1998 El Niño event (Fig. 6a), there was a layer $(60 \mathrm{~m})$ of homogeneous temperature $\left(>18^{\circ} \mathrm{C}\right)$, the thermocline sank $70 \mathrm{~m}$, and temperature increased $\sim 6^{\circ} \mathrm{C}$ in the upper $100 \mathrm{~m}$ relative to the time-series average (1998-2012). While the vertical position of the halocline was similar to the average, salinity increased by $\sim 0.9$ in the upper $100 \mathrm{~m}$ (Fig. 6b) but below this depth there was no apparent change. The chlorophyll concentrations in the upper $50 \mathrm{~m}$ were similar to the average, with a decrease of $\sim 0.5 \mathrm{mg} \mathrm{m}^{-3}$ in the area of the vertical gradient (Fig. 6c). During the moderate El Niño events of 2003 and 2010, the effects on the water-column structure were not as strong but still evident (sinking of the thermocline by $\sim 40 \mathrm{~m}$ ). The impact was greater on the 2010 chlorophyll concentration, which in turn was $~ 30 \%$ lower relative to the 1998 event (data not shown). The temperature composite for January a la biomasa del fitoplancton cercana a la superficie. En la serie de tiempo de la clorofila derivada de datos de satélite destacaron anomalías positivas altas en 2002 y 2003, con valores menores en 2011 y 2012 (Fig. 5d), sin una relación directa con el ciclo ENSO. En la serie de TSM y TDA resaltaron 2 eventos que impactaron a BSV, El Niño 1997-1998 (anomalías positivas altas) y La Niña 2010-2012 (anomalías negativas).

Durante el evento de El Niño 1998 (Fig. 6a), se presentó una capa homogénea $(60 \mathrm{~m})$ de temperatura $>18^{\circ} \mathrm{C}$, un hundimiento de $70 \mathrm{~m}$ en la termoclina y un incremento de $\sim 6{ }^{\circ} \mathrm{C}$ en los primeros $100 \mathrm{~m}$ de profundidad con respecto al promedio de largo plazo (1998-2012). Aunque la posición vertical de la haloclina fue muy similar al promedio, la bahía tuvo un incremento de $\sim 0.9$ en salinidad en los primeros $100 \mathrm{~m}$ de profundidad (Fig. 6b), pero no hubo un cambio aparente por debajo de esa profundidad. Las concentraciones de clorofila en los $50 \mathrm{~m}$ superiores fueron muy similares al promedio y disminuyeron $\sim 0.5 \mathrm{mg} \mathrm{m}^{-3}$ en la zona del gradiente vertical (Fig. 6c). Los efectos de los eventos de El Niño moderados de 2003 y 2010 fueron menores pero evidentes en la estructura de la columna de agua (hundimiento de la termoclina de $\sim 40 \mathrm{~m}$ ); el impacto mayor en la concentración de clorofila fue durante el evento de 2010, cuando la concentración fue $\sim 30 \%$ menor con respecto al evento de 1998 (datos no mostrados). La imagen compuesta de temperatura para enero de 1998 mostró valores superficiales de entre 19.5 y $20.5^{\circ} \mathrm{C}$, y el agua relativamente más cálida se ubicó hacia el centro y sur de la zona (Fig. 6d). El nivel del mar en el mismo mes fue siempre mayor que $70 \mathrm{~cm}$ para toda el área (Fig. 6e) debido al calentamiento superficial, y se observó un valor anómalo alto de TDA hacia la costa que no estuvo asociado con la temperatura. La clorofila derivada de datos de satélite en la bahía fue en promedio $<0.5 \mathrm{mg} \mathrm{m}^{-3}$, con algunos valores $>2 \mathrm{mg} \mathrm{m}^{-3}$ muy localizados en la zona costera (Fig. 6f).

Durante La Niña moderada de 1999 (http://www.ggweather.com/enso/oni.htm), los valores de las variables hidrográficas y la biomasa del fitoplancton en la bahía fueron cercanos al promedio (Fig. 7). En enero de 1999 la temperatura del agua fue $<15^{\circ} \mathrm{C}$ y la salinidad fue de $~ 33.6$ en los primeros $50 \mathrm{~m}$ de toda la bahía (Fig. 7a, b). La temperatura del agua estuvo $\sim 2.5^{\circ} \mathrm{C}$ por debajo del promedio de largo plazo, pero no hubo un cambio considerable en la salinidad. La capa homogénea de temperatura y salinidad se profundizó, y la termoclina y haloclina se ubicaron a $\sim 60 \mathrm{~m}$ de profundidad. Aunque la concentración de clorofila incrementó durante La Niña 1999 (Fig. 7c), en promedio no fue mayor que $0.5 \mathrm{mg} \mathrm{m}^{-3}$. Las condiciones en la bahía durante La Niña moderada de 2011 fueron muy similares durante 1999, a excepción de la posición más somera de la termoclina ( 30 m) y de la disminución en la temperatura $\left(0.5^{\circ} \mathrm{C}\right)$ y clorofila $\left(\sim 1.0 \mathrm{mg} \mathrm{m}^{-3}\right)$ promedio en los primeros $50 \mathrm{~m}$ de profundidad (datos no mostrados). Los valores superficiales de temperatura derivados de la imagen compuesta de enero de 1999 

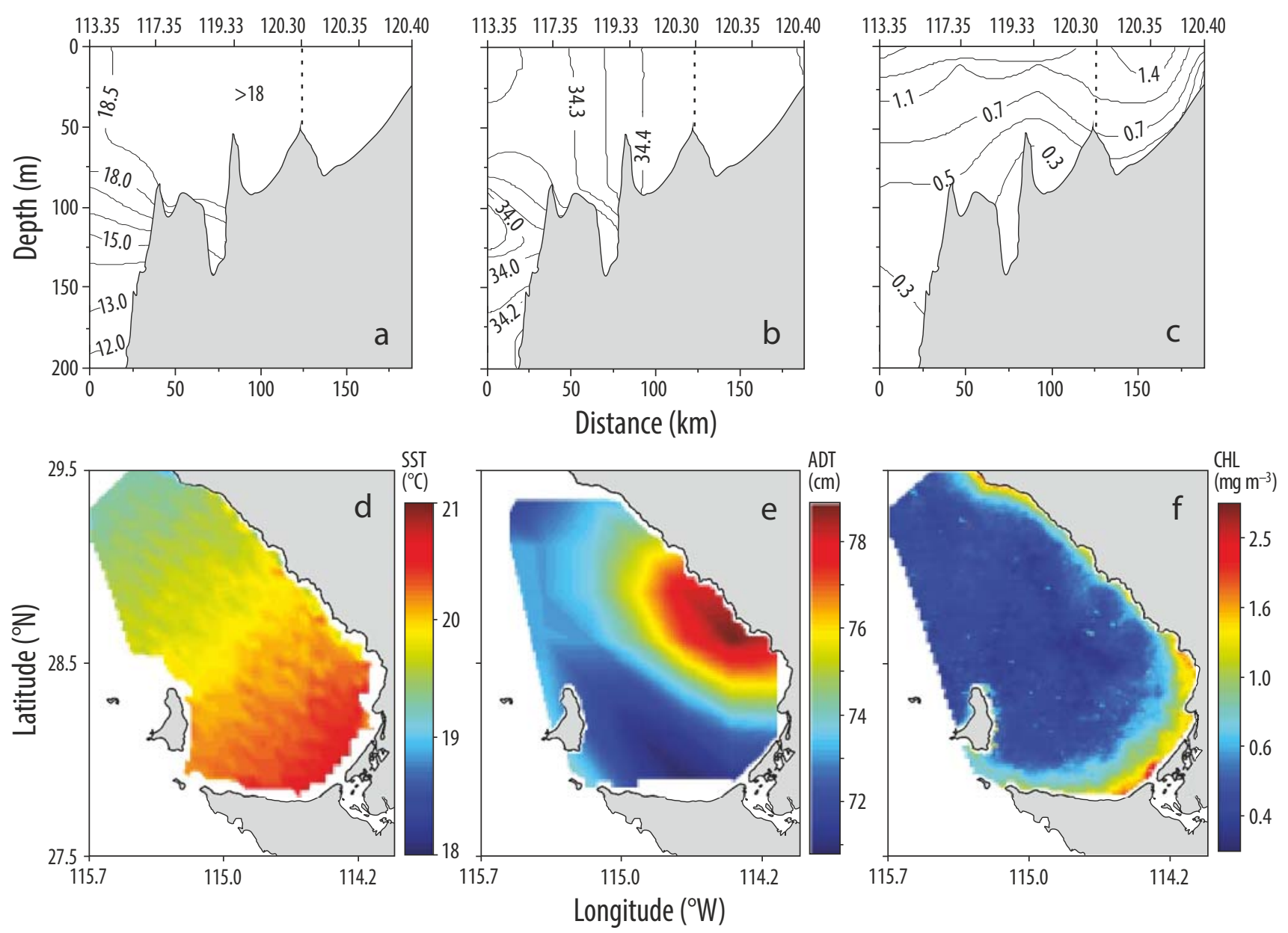

Figure 6. The upper panels show vertical sections of the variables measured in January 1998 along the transect shown in Figure 1a (dashed line indicates the change in direction at station 120.30): temperature (a), salinity (b), and chlorophyll $a$ (c). The lower panels show composite satellite images for January 1998: sea surface temperature (SST) (d), absolute dynamic topography (ADT) (e), and chlorophyll (CHL) (f).

Figura 6. Los paneles superiores muestran las secciones verticales de variables medidas durante enero de 1998 a lo largo del transecto que se muestra en la Figura 1a (la línea punteada indica el cambio de dirección a partír de la estación 120.30): temperatura (a), salinidad (b) y clorofila $a(\mathbf{c})$. Los paneles inferiores muestran las imágenes compuestas derivadas de datos de satélite durante enero de 1998: temperatura superficial del mar (SST) (d), topografía dinámica absoluta (ADT) (e) y clorofila (CHL) (f).

1998 showed surface values of $19.5-20.5^{\circ} \mathrm{C}$, the relatively warmer water occurring in the central-southern part (Fig. 6d). In the same month, sea level was $>70 \mathrm{~cm}$ for all the area (Fig. 6e) due to surface heating, with an anomalous, high ADT value towards the shore that was not associated with temperature. The satellite-derived chlorophyll was on average $<0.5 \mathrm{mg} \mathrm{m}^{-3}$, with some values $>2 \mathrm{mg} \mathrm{m}^{-3}$ in the coastal zone (Fig. 6f).

During the moderate 1999 La Niña event (http:// www.ggweather.com/enso/oni.htm), the hydrographic variables and phytoplankton biomass in the bay were similar to the average (Fig. 7). In January 1999, water temperature was $<15^{\circ} \mathrm{C}$ and salinity was $\sim 33.6$ in the upper $50 \mathrm{~m}$ throughout the bay (Fig. 7a, b). Water temperature was $\sim 2.5^{\circ} \mathrm{C}$ below the time-series average, while salinity did not change considerably. The homogeneous temperature and salinity layer estuvieron entre 15.5 y $16.5^{\circ} \mathrm{C}$, y el agua con temperatura $<15.5^{\circ} \mathrm{C}$ estuvo localizada hacia el noroeste de la zona costera (Fig. 7d). La TDA estuvo entre 52 y $58 \mathrm{~cm}$ (Fig. 7e), y los valores bajos se ubicaron hacia el centro de la bahía y no estuvieron asociados directamente con la TSM. Esta variable fue en promedio $20 \mathrm{~cm}$ menor que en enero de 1998 debido a la disminución de temperatura $\left(\sim 3^{\circ} \mathrm{C}\right)$ durante este periodo (1999) relacionada con los eventos de La Niña y surgencias costeras más intensas. Hacia el centro de la bahía, la clorofila promedio fue de $1.0 \mathrm{mg} \mathrm{m}^{-3}$, y los valores más altos $\left(\sim 2 \mathrm{mg} \mathrm{m}^{-3}\right)$ se ubicaron en el norte y sur de la zona costera (Fig. 7f).

Con base en la información obtenida para febrero de 2004, se caracterizó el efecto de la invasión anómala de agua subártica en la bahía (Fig. 8), ya que en ese periodo se observaron los valores menores de salinidad en la serie de 

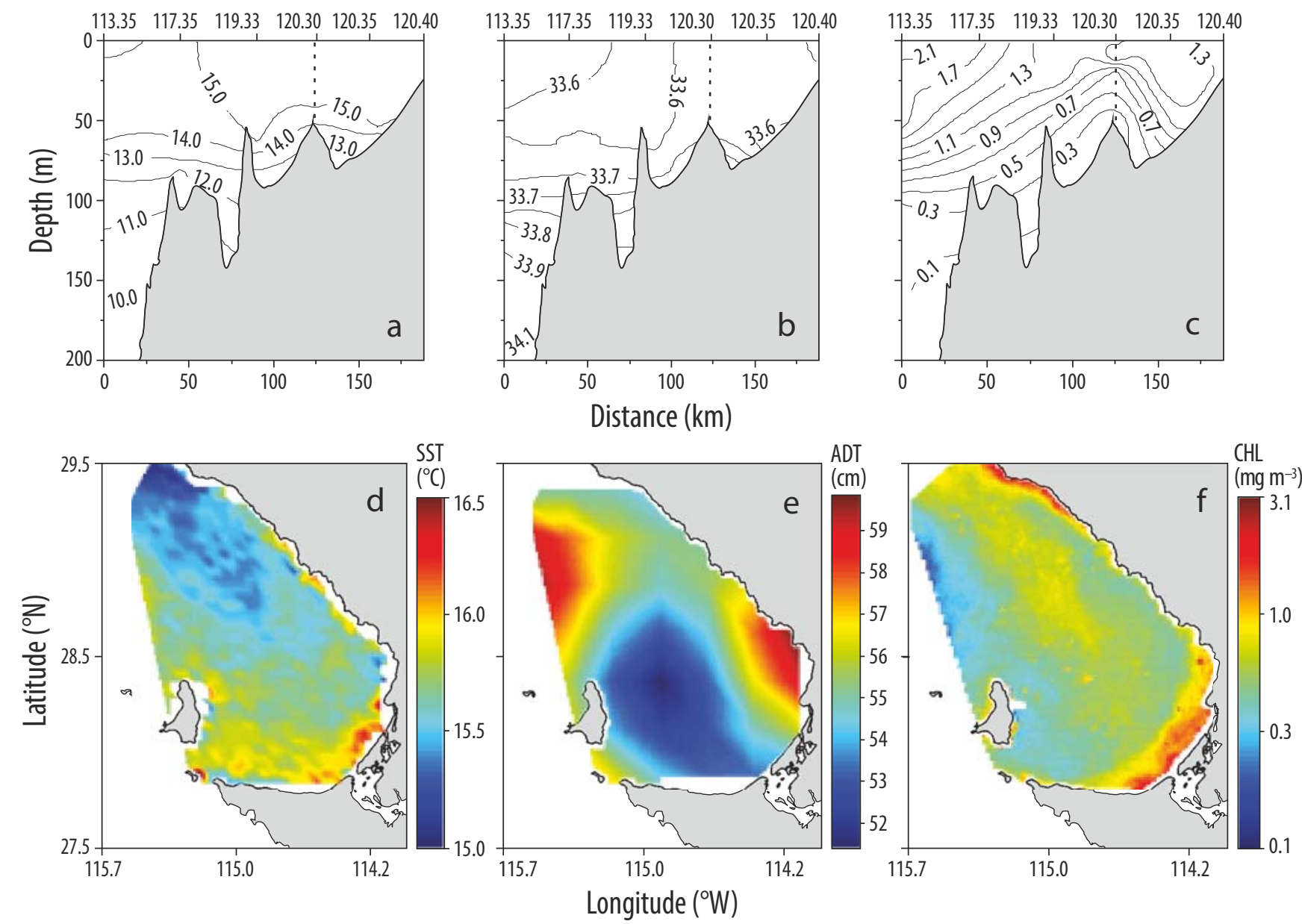

Figure 7. The upper panels show vertical sections of the variables measured in January 1999 along the transect shown in Figure 1a (the dashed line indicates the change in direction at station 120.30): temperature (a), salinity (b), and chlorophyll $a$ (c). The lower panels show composite satellite images for January 1999: sea surface temperature (d), absolute dynamic topography (e), and chlorophyll (CHL) (f).

Figura 7. Los paneles superiores muestran las secciones verticales de las variables medidas durante enero de 1999 a lo largo del transecto que se muestra en la Figura 1a (la línea punteada indica el cambio de dirección a partír de la estación 120.30): temperatura (a), salinidad (b) y clorofila $a(\mathbf{c})$. Los paneles inferiores muestran las imágenes compuestas derivadas de datos de satélite durante enero de 1999: temperatura superficial del mar (SST) (d), topografía dinámica absoluta (ADT) (e) y clorofila (CHL) (f).

deepened, and the thermocline and halocline were situated at $\sim 60 \mathrm{~m}$ depth. Though chlorophyll increased during the 1999 La Niña (Fig. 7c), on average it was not more than $0.5 \mathrm{mg} \mathrm{m}^{-3}$. The conditions in the bay during the moderate 2011 La Niña were very similar to those of 1999, except for a more shallow position of the thermocline $(\sim 30 \mathrm{~m})$, and lower average temperature $\left(0.5^{\circ} \mathrm{C}\right)$ and chlorophyll $\left(\sim 1.0 \mathrm{mg} \mathrm{m}^{-3}\right)$ in the upper $50 \mathrm{~m}$ (data not shown). The SST values derived from the composite image for January 1999 ranged from 15.5 to $16.5^{\circ} \mathrm{C}$, with water temperatures of $<15.5^{\circ} \mathrm{C}$ to the northwest of the coastal zone (Fig. 7d). The ADT ranged from 52 to $58 \mathrm{~cm}$ (Fig. 7e), the lower values occurring in the central part of the bay and not directly associated with SST. This variable was on average $20 \mathrm{~cm}$ lower than in January 1998 because of the decrease in temperature $\left(\sim 3^{\circ} \mathrm{C}\right)$ during this period (1999) related to the intense coastal upwelling and tiempo (Fig. 2b). La temperatura en los primeros $50 \mathrm{~m}$ fue $<16{ }^{\circ} \mathrm{C}$ (Fig. 8a), que se podría considerar dentro del promedio para el invierno de la región, y se observó una termoclina muy desarrollada a $\sim 50 \mathrm{~m}$ de profundidad en la sección norte. La entrada de agua "fresca" se originó principalmente por la boca norte, donde se observaron valores bajos de salinidad (33.2 a 33.3) entre 0.3 y 0.4 menor que el promedio para la bahía, la cual formó una columna de agua muy homogénea en salinidad en los primeros $60 \mathrm{~m}$ de profundidad (Fig. 8b). Esta condición de agua con baja salinidad generó concentraciones menores que el promedio de oxígeno disuelto ( $\sim .6 \mathrm{~mL} \mathrm{~L}^{-1}$; Fig. 8c) y clorofila del fitoplancton ( $\sim 1.0 \mathrm{mg} \mathrm{m}^{-3}$; Fig. 8d). El aporte de agua superficial con menor temperatura hacia la bahía (Fig. 8e), relacionada a valores bajos de TDA (Fig. 8f), se presentó solamente en una sección costera del norte como resultado de surgencias 

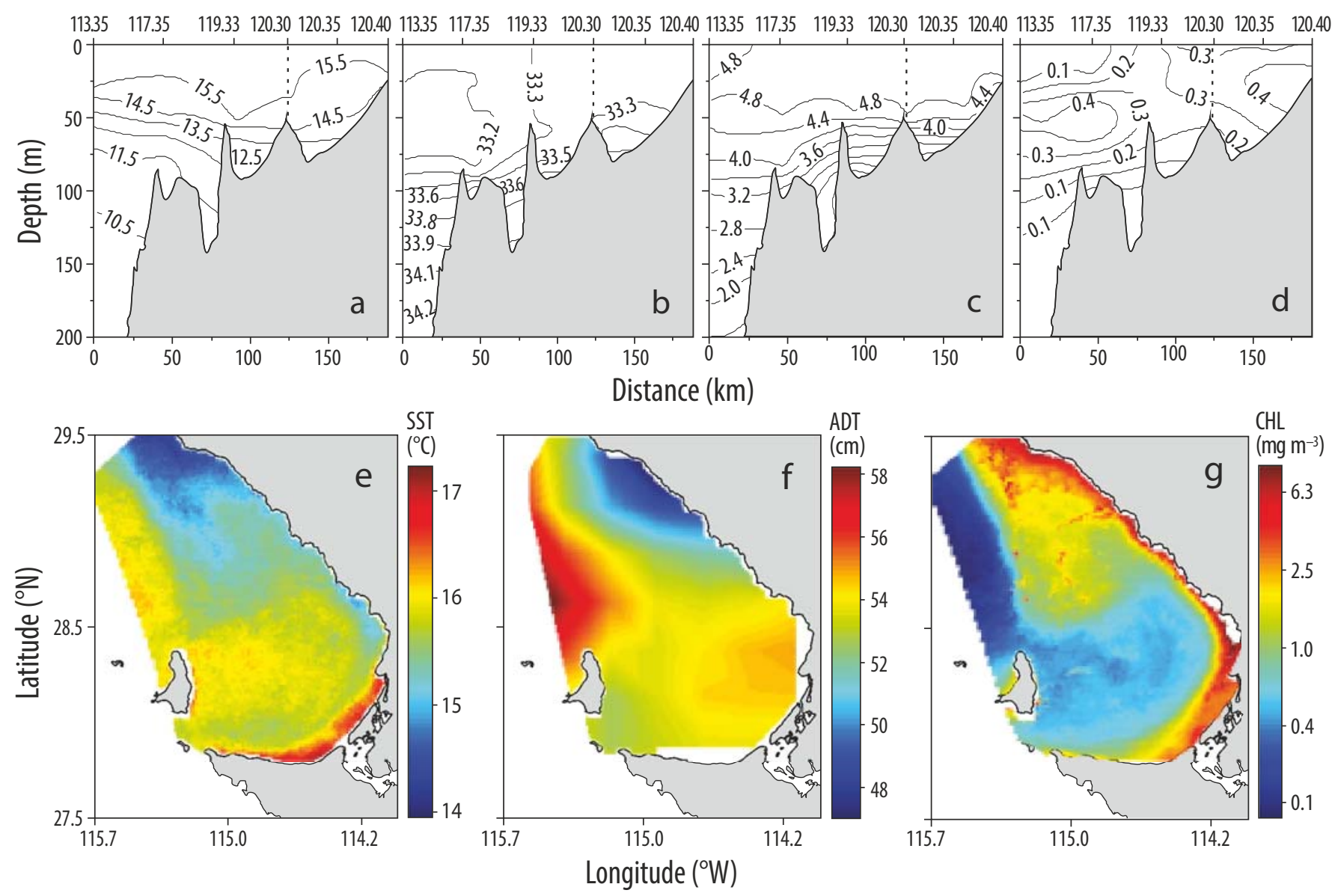

Figure 8. The upper panels show the hydrographic conditions along the transect shown in Figure 1a during February 2004 (the dashed line indicates the change in direction at station 120.30): temperature $\left({ }^{\circ} \mathrm{C}\right)(\mathbf{a})$, salinity (b), dissolved oxygen (mL $\left.\mathrm{L}^{-1}\right)(\mathbf{c})$, and chlorophyll $a$ $\left(\mathrm{mg} \mathrm{m}^{-3}\right)(\mathbf{d})$. The lower panels show composite satellite images for February 2004: sea surface temperature (SST) (e), absolute dynamic topography (ADT) (f), and chlorophyll (CHL) (g).

Figura 8. Los paneles superiores muestran las condiciones hidrográficas a lo largo del transecto de la Figura 1a durante febrero de 2004 (la línea punteada indica el cambio de dirección a partir de la estación 120.30): temperatura $\left({ }^{\circ} \mathrm{C}\right)$ (a), salinidad (b), oxígeno disuelto (mL $\mathrm{L}^{-1}$ ) (c) y clorofila $a\left(\mathrm{mg} \mathrm{m}^{-3}\right)(\mathbf{d})$. Los paneles inferiores muestran las imágenes compuestas derivadas de datos de satélite durante febrero de 2004 : temperatura superficial del mar (SST) (e), topografía dinámica absoluta (ADT) (f) y clorofila (CHL) (g).

La Niña events. Average chlorophyll was $1.0 \mathrm{mg} \mathrm{m}^{-3}$ in the central part of the bay, and values were higher $\left(\sim 2 \mathrm{mg} \mathrm{m}^{-3}\right)$ to the north and south along the coast (Fig. 7f).

Based on the information for February 2004, period when the lowest salinity values of the time series were observed (Fig. 2b), we characterized the effect of the anomalous intrusion of subarctic water into the bay (Fig. 8). Temperature in the upper $50 \mathrm{~m}$ was $<16^{\circ} \mathrm{C}$ (Fig. 8a), which can be considered average for winter in the region, and a well-developed thermocline was observed at $\sim 50 \mathrm{~m}$ depth in the northern section. The inflow of "fresh" water occurred mainly through the nothern mouth, where salinity values (33.2-33.3) were lower (by 0.3-0.4) than the average for the bay, forming a homogeneous water column in regard to salinity in the upper $60 \mathrm{~m}$ (Fig. 8b). Because of this low-salinity condition, the concentrations of dissolved oxygen $\left(\sim 0.6 \mathrm{~mL} \mathrm{~L}^{-1}\right.$; Fig. $\left.8 c\right)$ débiles frente a punta Canoas, las cuales generaron concentraciones promedio de la biomasa del fitoplancton de $\sim 0.5 \mathrm{mg} \mathrm{m}^{-3}$ (Fig. 8g). La TSM promedio en la bahía fue de $16^{\circ} \mathrm{C}$ y la altura del nivel del mar fue de entre 52 y $54 \mathrm{~cm}$ (Fig. 8e, f); los valores de ambos parámetros fueron muy cercanos a los obtenidos durante La Niña moderada de 1999.

\section{Discusión}

Con base en los promedios temporales de largo plazo (1998-2012), la columna de agua de los primeros $60 \mathrm{~m}$ de profundidad de BSV se puede considerar como un ecosistema con condiciones templadas $\left(15-17^{\circ} \mathrm{C}\right)$, salinidad característica del agua de la CC (33.5 a 33.7), alto contenido de oxígeno disuelto $\left(>5.0 \mathrm{~mL} \mathrm{~L}^{-1}\right)$ y concentraciones altas de la biomasa del fitoplancton $\left(>1.0 \mathrm{mg} \mathrm{m}^{-3}\right)$. Estos valores son 
and phytoplankton chlorophyll $a\left(\sim 1.0 \mathrm{mg} \mathrm{m}^{-3}\right.$; Fig. 8d) were lower than average. The inflow of surface water with lower temperature into the bay (Fig. 8e), associated with low ADT values (Fig. 8f), occurred only in one coastal section in the northern part of the bay as a result of weak upwelling off Punta Canoas, which generated average phytoplankton biomass concentrations of $\sim 0.5 \mathrm{mg} \mathrm{m}^{-3}$ (Fig. 8g). Average SST in the bay was $16^{\circ} \mathrm{C}$ and sea level rise was between 52 and $54 \mathrm{~cm}$ (Fig. 8e, f); these values are similar to those obtained during the moderate 1999 La Niña.

\section{Discussion}

The time-series (1998-2012) average values indicate that in the upper $60 \mathrm{~m}$ of the SVB water column conditions are temperate $\left(15-17^{\circ} \mathrm{C}\right)$, salinity is characteristic of CC water (33.5-33.7), dissolved oxygen content is high $\left(>5.0 \mathrm{~mL} \mathrm{~L}^{-1}\right)$, and phytoplankton concentrations are high $\left(>1.0 \mathrm{mg} \mathrm{m}^{-3}\right)$. These values are similar to those measured by the IMECOCAL program in coastal zones of the northwestern region of the Baja California Peninsula (Gaxiola-Castro et al. 2010b). The bay is thus a healthy epipelagic ecosystem with open circulation and sufficient ventilation, and with suitable hydrographic conditions for the respiration/oxidation processes of the organisms. In general, it is an area of high biological productivity, which generates a mesotrophic environment in relation to the phytoplankton biomass and maintains the conditions necessary for the growth and development of the marine food web.

The time series of the variables measured at $10 \mathrm{~m}$ depth reveal the effects of the anomalous intrusion of subarctic water and of the ENSO events that impacted all the region off Baja California (Durazo and Baumgartner 2002; Durazo et al. 2005; Gaxiola-Castro et al. 2008, 2010a; HerreraCervantes et al. 2014). El Niño events seem to have a greater effect on surface conditions than La Niña events given that temperate to cold conditions generally prevail in the bay because of the influence of CC water and upwelling of subsurface water in the northern coastal zone. The effects of the strong 1997-1998 El Niño on the physical variables are more evident, with an increase in both temperature $\left(\sim 8^{\circ} \mathrm{C}\right)$ and salinity ( 0.9). The anomalous occurrence of warm, more saline water close to the surface has also been observed outside the bay (IMECOCAL line 120) during this event, caused by the poleward advection of subtropical water (Durazo and Baumgartner 2002). While El Niño has an evident effect on the physics of the bay, it does not seem to have a big impact on chlorophyll, most likely because of changes in the dominant phytoplankton groups and/or selective grazing by zooplankton. Arroyo-Loranca et al. (2015) reported a decrease in satellite-derived chlorophyll off Punta Eugenia (immediately to the south of SVB) during the $1998 \mathrm{El}$ Niño event. During this El Niño, in SVB Lavaniegos et al. (2003) observed high richness of phytoplankton groups other than diatoms, such as armored dinoflagellates, cryptomonads, and nanoflagellates. similares a los valores medidos por el programa IMECOCAL en las zonas costeras de la región noroccidental de la península de Baja California (Gaxiola-Castro et al. 2010b). La bahía es, por lo tanto, un ecosistema epipelágico saludable con circulación abierta y ventilación suficiente, y con condiciones hidrográficas adecuadas en cuanto a procesos de respiración-oxidación para la existencia de los organismos que la habitan. En general, la zona tiene una producción biológica alta, lo que genera un ambiente mesotrófico con relación a la biomasa del fitoplancton y mantiene condiciones necesarias para el crecimiento y desarrollo de la trama trófica marina.

Las series de tiempo de las variables ambientales medidas a $10 \mathrm{~m}$ de profundidad muestran los efectos del ingreso anómalo de agua subártica y los eventos de ENSO que impactaron a toda la región frente a Baja California (Durazo y Baumgartner 2002; Durazo et al. 2005; Gaxiola-Castro et al. 2008, 2010a; Herrera-Cervantes et al. 2014). Las condiciones superficiales parecen estar afectadas mayormente por eventos de El Niño que por eventos de La Niña debido a que las características de la bahía son en promedio de templadas a frías como resultado de la influencia del agua de la CC y de los afloramientos de agua subsuperficial en la costa norte. Los efectos de El Niño muy fuerte que impactó en 1997-1998 son más evidentes en las variables físicas, con un incremento en la temperatura $\left(\sim 8^{\circ} \mathrm{C}\right)$ y salinidad $(\sim 0.9)$. Las anomalías de agua cálida y más salina cercana a la superficie fueron también reportadas fuera de la bahía (línea 120 de la red IMECOCAL) durante este evento, originadas por la adveccion de agua subtropical hacia el polo (Durazo y Baumgartner 2002). Aunque hay una respuesta evidente del efecto de El Niño en la física de la bahía, no hay un impacto notorio en la clorofila, tal vez debido a cambios en los grupos dominantes del fitoplancton y/o el pastoreo selectivo del zooplancton. Arroyo-Loranca et al. (2015) mostraron que durante el evento de El Niño 1998 hubo una disminución en la clorofila derivada de datos de satélite en la zona costera frente a punta Eugenia, inmediatamente al sur de BSV. Durante este evento, Lavaniegos et al. (2003) observaron en la bahía una riqueza alta en otros grupos del fitoplancton diferente a las diatomeas, como dinoflagelados tecados, criptomonas y nanoflagelados. Esto pudo haber ocasionado que la biomasa permaneciera sin cambios notorios, no así la composición de los grupos del plancton (tamaño de fitoplancton y zooplancton, grupos funcionales, etc.) ni los posibles efectos en la trama trófica. Kahru y Mitchell (2000) hipotetizaron que el incremento de la clorofila derivada de datos de satélite en la zona oceánica frente a BSV durante El Niño 1997-1998 fue el resultado del aumento de cianobacterias fijadoras de nitrógeno.

De acuerdo con la climatología obtenida a partir de la información de sensores remotos para el periodo de estudio, la bahía presenta una alta variabilidad estacional, con marcadas diferencias en la temperatura superficial y la clorofila. Esta variabilidad está asociada principalmente a los cambios 
As a result, the biomass may not undergo notable changes, but changes may occur in the composition of the plankton groups (phytoplankton and zooplankton size, functional groups, etc.) that could affect the food web. Kahru and Mitchell (2000) hypothesized that the increase in satellitederived chlorophyll in the oceanic zone off SVB during the 1997-1998 El Niño was the result of an increase in nitrogenfixing cyanobacteria.

The climatology obtained based on remote sensing data for the study period shows that SVB presents high seasonal variability, with marked differences in surface temperature and chlorophyll. This variability is mainly associated with changes in the flow of the CC (Durazo 2009, 2015) and with coastal upwelling events that are more intense in spring and summer (Palacios-Hernández et al. 1996). The regional wind conditions change in summer and autumn (Castro and Martínez 2010), modifying the equatorward transport of water and the coastal upwelling pattern. This affects SVB as surface temperature increases and chlorophyll concentration decreases because of greater stratification in the euphotic zone. In the region outside the bay, the flow is predominantly poleward in late summer and autumn (Durazo 2015, Zaitsev et al. 2014), and there is limited inflow of warm water near the surface via the southern mouth. The seasonal and interannual effect on chlorophyll is also evident off Punta Eugenia, the concentrations being higher $\left(>5 \mathrm{mg} \mathrm{m}^{-3}\right.$ ) from March to August and lower $\left(\sim 1.2 \mathrm{mg} \mathrm{m}^{-3}\right)$ from September to February (Arroyo-Loranca et al. 2015).

Given that it is located in an oceanographic transition zone between temperate conditions, influenced by the equatorward flow of the CC in spring and summer, and subtropical conditions, influenced by the poleward transport of coastal water in late summer and autumn, SVB is affected by large-scale tropical events such as El Niño and by events that originate in the subpolar region of the Pacific. The 1997-1998 El Niño primarily impacted the hydrographic variables of the bay, but did not have a strong effect on phytoplankton chlorophyll. During La Niña events, however, none of the variables were strongly affected, except for chlorophyll that increased as a result of the intensification of coastal upwelling along the northern coastal zone. Nonetheless, neither the El Niño nor the La Niña events significantly affected the satellite-derived chlorophyll near the surface. Phytoplankton biomass does not change substantially in the bay during El Niño events because of local dynamic processes and/or because of the diverse response of the epipelagic ecosystem to other processes such as the remineralization of organic matter and the dominance of other phytoplankton and zooplankton groups. For example, the 1997-1998 El Niño had a greater effect on the physical variables than on chlorophyll, most likely because the most important changes in the biological aspects were related to the abundance of the phytoplankton species present in the epipelagic zone and to selective grazing by zooplankton. en el flujo de la CC (Durazo 2009, 2015) y a los eventos de surgencias costeras que son más intensos durante primavera y verano (Palacios-Hernández et al. 1996). En verano y otoño cambian las condiciones del viento en la región (Castro y Martínez 2010), lo que modifica el transporte del agua hacia el ecuador y el patrón de las surgencias costeras. Esto afecta a BSV al generar altos valores de temperatura superficial y bajas concentraciones de clorofila debido a la mayor estratificación de la zona eufótica. Hacia finales del verano y el otoño, en la región fuera de la bahía domina el flujo de agua hacia el polo (Durazo 2015, Zaitsev et al. 2014), y la entrada de agua cálida cercana a la superficie por la boca sur es limitada. En el área frente a punta Eugenia, el efecto estacional e interanual sobre la clorofila también es evidente, ya que las concentraciones son mayores $\left(>5 \mathrm{mg} \mathrm{m}^{-3}\right)$ de marzo a agosto y menores $\left(\sim 1.2 \mathrm{mg} \mathrm{m}^{-3}\right)$ de septiembre a febrero (ArroyoLoranca et al. 2015).

Debido a su localización en una zona de transición oceanográfica entre condiciones templadas, influenciadas por el flujo dominante de la CC hacia el ecuador en primavera y verano, y condiciones subtropicales, influenciadas por el agua costera transportada hacia el polo a finales de verano y otoño, BSV es afectada por eventos tropicales de gran escala espacial como El Niño y los eventos originados en la región subpolar del Pacífico. El Niño 1997-1998 afectó mayormente las variables hidrográficas de la bahía, sin un efecto muy drástico en la clorofila del fitoplancton. Sin embargo, no se presentaron condiciones muy diferentes al promedio en todas las variables durante los eventos de La Niña, excepto la posible intensificación de las surgencias costeras en la costa norte que generó concentraciones altas de clorofila. No obstante, los eventos de El Niño y La Niña no afectaron sustancialmente a la clorofila del fitoplancton superficial derivada de los sensores remotos. La biomasa del fitoplancton no cambia sustancialmente en la bahía durante eventos de El Niño debido a los procesos dinámicos locales y/o a las diversas respuestas del ecosistema epipelágico a otros procesos como la remineralización de la materia orgánica y la dominancia de otros grupos del fitoplancton y del zooplancton. Por ejemplo, en BSV, El Niño 1997-1998 tuvo un mayor efecto en las variables físicas y menor en la clorofila, ya que posiblemente los cambios más importantes en los aspectos biológicos estuvieron relacionados con las abundancias de las especies del fitoplancton presentes en la zona epipelágica y con el pastoreo diferenciado del zooplancton.

Se ha identificado la presencia de Agua Subtropical Subsuperficial en la zona exterior de BSV durante El Niño 1997-1998 (Durazo y Baumgartner 2002); sin embargo, con nuestra información no fue evidente la caracterización de esta agua en el interior de la bahía para el mismo periodo. De acuerdo con la relación temperatura-salinidad obtenida con todos los datos de los cruceros IMECOCAL 1997-2012 para la bahía, la salinidad fue siempre menor que 34.5 (datos no mostrados), lo que se puede interpretar como salinidad característica de agua subártica modificada (Durazo y 
Durazo and Baumgartner (2002) identified the presence of Subtropical Subsurface Water in the exterior part of SVB during the 1997-1998 El Niño. In the present study, however, we did not identify this water inside the bay during the same period. According to the temperature-salinity relationship obtained with all the SVB data from the 1997-2012 IMECOCAL cruises, salinity was always $<34.5$ (data not shown), which corresponds to salinity associated with modified subarctic water (Durazo and Baumgartner 2002, Durazo et al. 2010). According to Zaitsev et al. (2014), to identify the presence of Subtropical Subsurface Water in this region, salinity values must be greater than 34.7 , but there was no evidence of this water during the 1998, 2003, and 2010 El Niño events. Apparently, the predominant surface circulation in the northern part of the bay and the shallower depth at the southern mouth hinder the inflow of saltier subsurface water, both in late summer and autumn (after the upwelling season) and during El Niño events when there is increased poleward flow.

The intrusion of subarctic water was a large-scale event apparently not directly related to the ENSO cycle. In the CCS, this event was more dominant than the moderate 2003 El Niño, which began to decline during the first months of that year (Venrick et al. 2003). The anomalous intrusion of subarctic water in the CCS was first observed in July 2002 off the coast of Oregon (Freeland et al. 2003) and was still evident until 2004-2005 off California (Goericke et al. 2004, 2005) and Baja California (Durazo et al. 2005; Gaxiola-Castro et al. 2008, 2010b; Herrera-Cervantes et al. 2014).

The inflow and permanence over several years (2003-2006) of less saline water (Fig. 2b) had strong repercussions on SVB. Salinity decreased, the halocline (nutricline) sinking to more than $80 \mathrm{~m}$ depth or to where the bottom permitted (Fig. 8b). The bay responded with low dissolved oxygen $\left(\sim 4.4 \mathrm{~mL} \mathrm{~L}^{-1}\right)$ and chlorophyll $\left(0.3 \mathrm{mg} \mathrm{m}^{-3}\right)$ values, which may indicate high oxygen consumption associated with respiration (oxidation) and/or decreased biological production due to the sinking of the thermocline. Gaxiola-Castro et al. (2008, 2010b) reported high positive macrozooplankton volume anomalies in the IMECOCAL region, asociated with high negative anomalies of integrated water-column chlorophyll levels. These authors associated the decline in phytoplankton biomass with zooplankton grazing and with strong stratification due to the large amount of low-density water in the upper $100 \mathrm{~m}$ that prevented vertical mixing and nutrient input to the euphotic zone. During this period, the IMECOCAL region was associated with positive anomalies of the main zooplankton groups, such as crustaceans, tunicates, and carnivores (Lavaniegos et al. 2015), and thus with low phytoplankton biomass. During the anomalous intrusion of subarctic water, mean water-column chlorophyll concentration in SVB was 30\% lower than that measured during the 1997-1998 El Niño, when the halocline structure was similar but with high salinity values. This caused a very
Baumgartner 2002, Durazo et al. 2010). De acuerdo con Zaitsev et al. (2014), los valores de salinidad deberían ser mayores que 34.7 para caracterizar la presencia de Agua Subtropical Subsuperficial en esa región, pero no se encontraron evidencias de esta agua aun durante los eventos de El Niño 1998, 2003 y 2010. Al parecer, la circulación superficial predominante en la parte norte de la bahía y la batimetría somera en la boca sur impiden la entrada de agua subsuperficial con mayor salinidad, tanto después de la época de surgencias (verano tardío y otoño) como durante los eventos de El Niño cuando hay un mayor transporte de agua hacia el polo.

El ingreso anómalo de agua subártica fue un evento de gran escala que aparentemente no estuvo relacionado con el ciclo ENSO. En el SCC este evento dominó sobre un El Niño 2003 moderado, el cual empezó a declinar durante los primeros meses de ese año (Venrick et al. 2003). El ingreso anómalo de agua subártica en el SCC fue observado por primera vez en julio de 2002 frente a las costas de Oregon (Freeland et al. 2003) y fue todavía evidente al menos hasta 2004-2005 frente a California (Goericke et al. 2004, 2005) y Baja California (Durazo et al. 2005; Gaxiola-Castro et al. 2008, 2010b; Herrera-Cervantes et al. 2014).

El ingreso y permanencia por varios años (2003-2006) de agua con menor salinidad (Fig. 2b) tuvo repercusiones en BSV. La salinidad disminuyó y la haloclina (nutriclina) se hundió a más de $80 \mathrm{~m}$ de profundidad o hasta donde el fondo lo permitió (Fig. 8b). La bahía respondió con valores muy bajos de oxígeno disuelto $\left(\sim 4.4 \mathrm{~mL} \mathrm{~L}^{-1}\right)$ y de clorofila $\left(0.3 \mathrm{mg} \mathrm{m}^{-3}\right)$, lo que podría indicar un alto consumo de oxígeno por procesos de respiración (oxidación) y/o una producción biológica muy disminuida debido al hundimiento de la termoclina. Gaxiola-Castro et al. (2008, 2010b) reportaron anomalías positivas altas del volumen del macrozooplancton en la región IMECOCAL, asociadas además con anomalías negativas muy altas de la clorofila integrada en la columna de agua. Estos autores relacionaron la disminución en la biomasa del fitoplancton con el pastoreo del zooplancton y con la estratificación muy fuerte debida a la gran cantidad de agua con menor densidad en los primeros $100 \mathrm{~m}$ de profundidad, la cual impidió la mezcla vertical y el aporte de nutrientes hacia la zona eufótica. Durante este periodo, la región IMECOCAL estuvo asociada con anomalías positivas de los principales grupos del zooplancton, como crustáceos, tunicados y carnívoros (Lavaniegos et al. 2015), y consecuentemente valores bajos de la biomasa del fitoplancton. Durante el evento de ingreso anómalo de agua subártica, la clorofila promedio en la columna de agua de BSV fue $30 \%$ menor que la medida durante El Niño 1997-1998, cuando la haloclina presentó una estructura vertical similar pero con valores altos en salinidad. Esto ocasionó una respuesta muy diferente en la biomasa del fitoplancton, asociada también a los grupos del zooplancton ya que hubo una abundancia 
different phytoplankton biomass response, also related to the zooplankton groups since there was a high abundance of salps (33.3 ind $\mathrm{m}^{-3}$ ) in the bay during this period (Lavaniegos et al. 2015).

\section{ACKNOWLEDGMENTS}

Funding for the IMECOCAL campaigns was provided by the National Council of Science and Technology (CONACYT, Mexico, projects 129140, 99252, 23947, 47044, 42569, G35326T, 017P\D1-1297, G0041T, and 23804). LMMF and EGO received scholarships from CONACYT and the Sistema Nacional de Investigadores (SNI). GGC was supported by SNI-CONACYT. We thank the participants of the IMECOCAL campaigns aboard the $\mathrm{R} / \mathrm{V}$ Francisco de Ulloa and CICESE for its support of the IMECOCAL program.

English translation by Christine Harris.

\section{REFERENCES}

Amador-Buenrostro A, Argote-Espinoza ML, Mancilla-Peraza M, Figueroa-Rodríguez M. 1995. Short-term variations of the anticyclonic circulation in Bahía Sebastián Vizcaíno, Baja California = Variaciones de periodo corto de la circulación anticiclónica en bahía Sebastián Vizcaíno, Baja California. Cienc. Mar. 21: 201-223.

Arroyo-Loranca RG, Álvarez-Borrego S, Ortiz-Figueroa M, Calderón-Aguilera LE. 2015. Spatial and temporal variation of satellite-derived phytoplankton biomass and production in the California Current System off Punta Eugenia, during 1997-2012. Hidrobiológica 25: 321-334.

Bjorkstedt EP, Goericke R, McClatchie S, Weber E, Watson W, et al. 2010. State of the California Current 2009-2010: Regional variation persists through transition from La Niña to El Niño (and back?). CalCOFI Rep. 51: 39-69.

Bjorkstedt EP, Goericke R, McClatchie S, Weber E, Watson W, et al. 2011. State of the California Current 2010-2011: Regionally variable responses to a strong (but fleeting?) La Niña. CalCOFI Rep. 52: 36-68.

Castro R, Martínez JA. 2010. Variabilidad espacial y temporal del campo de viento. In: Gaxiola-Castro G, Durazo R (eds.), Dinámica del Ecosistema Pelágico frente a Baja California 1997-2007. Secretaría de Medio Ambiente y Recursos Naturales, Instituto Nacional de Ecología, México, D.F., pp. 129-147.

Dawson EY. 1952. Circulation within Bahía Vizcaíno, Baja California, and its effects on marine vegetation. Am. J. Bot. 39(7): 425-432.

Durazo R. 2009. Climate and upper ocean variability off Baja California, Mexico: 1997-2008. Prog. Oceanogr. 83: 361-368. http://dx.doi.org/10.1016/j.pocean.2009.07.043

Durazo R. 2015. Seasonality of the transitional region of the California Current off Baja California. J. Geophys. Res. Oceans 120: 1173-1196. http://dx.doi.org/10.1002/2014JC010405.

Durazo R, Baumgartner TR. 2002. Evolution of oceanographic conditions off Baja California: 1997-1999. Prog. Oceanogr. 54:7-31.

http://dx.doi.org/10.1016/S0079-6611(02)00041-1 promedio alta de salpas (33.3 ind $\mathrm{m}^{-3}$ ) en la bahía durante el periodo del agua subártica (Lavaniegos et al. 2015).

\section{Agradecimientos}

El financiamiento para realizar las campañas oceanográficas IMECOCAL se obtuvo mediante el Consejo Nacional de Ciencia y Tecnología (CONACYT, México; proyectos 129140, 99252, 23947, 47044, 42569, G35326T, 017P\D1-1297, G0041T y 23804). Muy especialmente agradecemos al CONACYT y al Sistema Nacional de Investigadores (SNI) por las becas otorgadas a LMMF y EGO. GGC tiene una beca del SNI-CONACYT. Agradecemos a los participantes en las campañas IMECOCAL a bordo del B/O Francisco de Ulloa del CICESE, de donde se obtuvo la información hidrográfica utilizada en este trabajo.

Durazo R, Gaxiola-Castro G, Lavaniegos BE, Castro-Valdez R, Gómez-Valdés J, Mascarenhas Jr AS. 2005. Oceanographic conditions west of the Baja California coast, 2002-2003: A weak El Niño and subarctic water enhancement = Condiciones oceanográficas frente a la costa occidental de Baja California, 2002-2003: Influencia de un El Niño débil y del incremento de agua subártica. Cienc. Mar. 31: 537-552.

Durazo R, Ramírez-Manguilar AM, Miranda LE, Soto-Mardones LA. 2010. Climatología de variables hidrográficas. In: GaxiolaCastro G, Durazo R (eds.), Dinámica del Ecosistema Pelágico frente a Baja California 1997-2007. Secretaría de Medio Ambiente y Recursos Naturales, Instituto Nacional de Ecología, México, D.F., pp. 25-57.

Espinosa-Carreón TL, Gaxiola-Castro G, Durazo R, De la CruzOrozco ME, Norzagaray-Campos M, Solana-Arellano E. 2015. Influence of anomalous subarctic water intrusion on phytoplankton production off Baja California. Cont. Shelf Res. 92: 108-121. http://dx.doi.org/10.1016/j.csr.2014.10.003

Freeland HJ, Gatien G, Huyer A, Smith RL. 2003. Cold halocline in the northern California Current: An invasion of subarctic water. Geophys. Res. Lett. 30: 1141. http://dx.doi.og/10.1029/2002GL016663.

Gaxiola-Castro G, Durazo R, Lavaniegos B, De la Cruz-Orozco ME, Millán-Núñez E, Soto-Mardones L, Cepeda-Morales J. 2008. Pelagic ecosystem response to interannual variability off Baja California $=$ Respuesta del ecosistema pelágico a la variabilidad interanual del océano frente a Baja California. Cienc. Mar. 34: 263-270.

Gaxiola-Castro G, Cepeda-Morales J, Nájera-Martínez S, EspinosaCarreón TL, De la Cruz-Orozco ME, Sosa-Avalos R, AguirreHernández E, Cantú-Ontiveros JP. 2010a. Biomasa y producción del fitoplancton. In: Gaxiola-Castro G, Durazo R (eds.), Dinámica del Ecosistema Pelágico frente a Baja California 1997-2007. Secretaría de Medio Ambiente y Recursos Naturales, Instituto Nacional de Ecología, México, D.F., pp. 59-85.

Gaxiola-Castro G, Lavaniegos Espejo BE, Martínez Alcalá JA, Castro R, Espinosa Carreón TL. 2010b. Pelagic ecosystem response to climate variability in the Pacific Ocean off Baja 
California. In: Simard SW, Austin ME (eds.), Climate Change and Variability. Sciyo In-Tech, Croatia, pp. 163-182.

Goericke R, Bograd SJ, Gaxiola-Castro G, José Gómez-Valdes J, Hooff R, et al. 2004. The state of the California Current, 2003-2004: A rare "normal” year. CalCOFI Rep. 45: 27-59.

Goericke R, Venrick E, Mantyla A, Bograd SJ, Schwing FB, et al. 2005. The state of the California Current, 2004-2005: Still cool. CalCOFI Rep. 46: 32-71.

Hayward TL, Baumgartner TR, Checkley DM, Durazo R, GaxiolaCastro G, et al. 1999. The state of the California Current in 1998-1999: Transition to cool-water conditions. CalCOFI Rep. 40: 29-62.

Helm I, Jalukse L, Vilbaste M, Leito I. 2009. Micro-Winkler titration method for dissolved oxygen concentration measurement. Anal. Chim. Acta 648(2): 167-173. http://dx.doi.org/10.1016/j.aca.2009.06.067.

Herrera-Cervantes H, Lluch-Cota SE, Lluch-Cota DB, Gutierrez-deVelazco G. 2014. Interannual correlations between sea surface temperature and concentration of chlorophyll pigment off Punta Eugenia, Baja California, during different remote forcing conditions. Ocean Sci. 10(3):1-11. http://dx.doi.org/10.5194/os-10-345-2014

Holm-Hansen O, Lorenzen CJ, Holmes RW, Strickland JDH. 1965. Fluorometric determination of chlorophyll. J. Cons. int. Explor. Mer. 30: 3-15.

http://dx.doi.org/10.1093/icesjms/30.1.3

Kahru M, Mitchell BG. 2000. Influence of the 1997-98 El Niño on the surface chlorophyll in the California Current. Geophys. Res. Lett. 27: 2937-2940. http:dx.doi.org/10.1029/2000GL011486

Lavaniegos BE. 1995. Production of the euphausiid Nyctiphanes simplex in Vizcaíno Bay, western Baja California. J. Crust. Biol. 15(3): 444-453. http://dx.doi.org/10.1163/193724095X00451

Lavaniegos BE. 2014. Pelagic amphipod assemblages associated with subarctic water off the west coast of the Baja California peninsula. J. Mar. Syst. 132: 1-12. http://dx.doi.org/10.1016/j.jmarsys.2013.12.012

Lavaniegos BE, Gaxiola-Castro G, Jiménez-Pérez LC, GonzálezEsparza MR, Baumgartner T, García-Cordova J. 2003. 1997-98 El Niño effects on the pelagic ecosystem of the California current off Baja California, Mexico. Geofis. Int. 42: 483-494.

Lavaniegos BE, Jiménez-Pérez LC, Gaxiola-Castro G. 2002. Plankton response to El Niño 1997-1998 and La Niña 1999 in the southern region of the California Current. Prog. Oceanogr. 54: 33-58. http://dx.doi.org/10.1016/S0079-6611(02)00042-3

Lavaniegos BE, Molina-González O, Murcia-Riaño M. 2015. Zooplankton functional groups from the California Current and climate variability during 1997-2013. CICIMAR Oceánides 30: 45-62.

Lynn RJ, Baumgartner T, Garcia J, Collins CA, Hayward TL, et al. 1998. The state of the California Current, 1997-1998: Transition to El Niño conditions. CalCOFI Rep. 39: 25-49.

Mancilla-Peraza M, Palacios-Hernández E, López-Castillo G. 1993. Hydrographic variability in Bahía Vizcaíno, Baja California, Mexico = Variabilidad hidrográfica de Bahía Vizcaíno, Baja California, México. Cienc. Mar. 19: 265-284.

McClatchie S, Goericke R, Schwing FB, Bograd SJ, Peterson WT, et al. 2009. The state of the California Current, spring 2008-2009: Cold conditions drive regional differences in coastal production. CalCOFI Rep. 50: 43-68.

McEwen GF. 1916. Summary and interpretation of the hydrographic observations made by the Scripps Institution for Biological Research of the University of California, 1908 to 1915. Univ. Calif. Pub. Zool. 15: 255-356.

Palacios-Hernández E, Argote EM, Amador BA, Mancilla PM. 1996. Simulación de la circulación barotrópica inducida por viento en Bahía Sebastián Vizcaíno, B.C. Atmósfera 9: 171-188.

Venrick E, Bograd S, Checkley D, Durazo R, et al. 2003. The state of the California Current, 2002-2003: Tropical and subarctic influences vie for dominance. CalCOFI Rep. 44: 28-60.

Venrick E, Hayward TL. 1984. Determining chlorophyll on the 1984 CalCOFI surveys. CalCOFI Rep. 25: 74-79.

Wyllie JG. 1961. The water masses of Sebastian Vizcaino Bay. CalCOFI Rep. 8: 83-93.

Yentsch CS, Menzel DW. 1963. A method for the determination of phytoplankton chlorophyll and phaeophytin by fluorescence. Deep-Sea Res. Oceanogr. 10(3): 221-231. http://dx.doi.org/10.1016/0011-7471(63)90358-9

Zaitsev O, Trasviña-Castro A, Linero-Cueto J, Gaxiola-Castro G, Cepeda-Morales J. 2014. Oceanographic conditions over the continental shelf off Magdalena Bay (Mexico) in 2011-2012 = Condiciones oceanográficas en la plataforma continental frente a bahía Magdalena (México) en 2011-2012. Cienc. Mar. 40: 89-112.
Received December 2015, accepted March 2016. 